\title{
Post-divorce coaching: a new intervention to facilitate divorce adjustment
}

\author{
Pendar Fazel $^{1}$, Siamak Tahmasebi Garmtani ${ }^{2}$, Seyed Ali Hosseini Almadani ${ }^{3}$ \\ 1-Student, Department of Psychology, Azad University North Tehran Branch, Tehran, Iran (Corresponding Author). \\ E-mail: fazel.pendar@gmail.com \\ 2- Assistant Professor, Department of Abnormal Psychology, University of Social Welfare and Rehabilitation, \\ Tehran, Iran. \\ 3- Assistant Professor, Department of Psychology, Azad University North Tehran Branch, Tehran, Iran.
}

Received: 06/01/2020

Accepted: 04/02/2020

\begin{abstract}
Introduction: Family has been the most fundamental social institution underlying societies and human history. Divorce is one of the social issues, which often causes problems for family members and make them vulnerable. Despite all efforts, have done to date, to prevent divorce, statistics show that the divorce rate is growing day by day.

Aim: The present study aims is to provide a framework for Post-divorce Coaching. The result has been categorized and presented in the three sections: 1. Definitions of coaching and Related Areas, 2. Family Coaching, 3. Post-divorce Adjustment and the coaching interventions required.

Method: This is a descriptive-analytic review study. Comprehensively review the research conducted in the field of coaching. In the first phase, a total of 243 English articles and 3 registered Persian articles selected. Finally, after the final review, 84 articles chose.

Results: As research in coaching is very limited, there is no record for coaching interventions to strengthen the lives of divorced people around the world. In this regard, the effectiveness of future-oriented interventions like coaching can be effective in reducing the issues caused by divorce. Therefore coaching is a useful intervention that can play a key role in Post-Divorce adjustment.
\end{abstract}

Conclusion: Although divorce has consequences for the members involved, Post-Divorce Coaching intervention can promote the quality of life in divorcees and help them manage the changes imposed by divorce so, divorce adjustment will be the result of that.

KeyWords: Post-divorce coaching, Divorce coaching, Divorce adjustment, Post divorce adjustment

How to cite this article : Fazel P, Tahmasebi Garmtani S, Hosseini Almadani SA. Post-divorce coaching: a new intervention to facilitate divorce adjustment. Shenakht Journal of Psychology and Psychiatry. 2020; 7 (1): 153-175 .URL: http://shenakht.muk.ac.ir/article-1-885-fa.pdf

Copyright $\odot 2018$ the Author (s). Published by Kurdistan University of Medical Sciences. This is an open access article distributed under the terms of the Creative Commons Attribution-Non Commercial License 4.0 (CCBY-NC), where it is permissible to download, share, remix, transform, and buildup the work provided it is properly cited. The work cannot be used commercially without permission from the journal. 


\title{
رهيارى پس از طلاق مداخله جديدى جهت تسهيل ساز كارى پس از طلاق
}

\author{
هندار فاضل'، سيامك طهماسبى تر متانى '، سيد على حسينى المدنى \\ fazel.pendar@gmail.com : ا.دانشجو، گروه روانشناسى، دانشكاه آزاد اسلامى واحد تهران شمال، تهران، ايران (مولف مسئول). ايميل

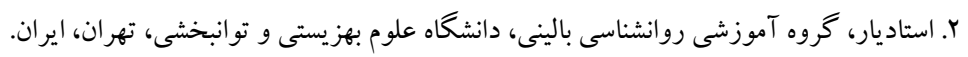

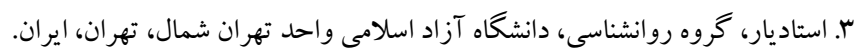

مقدمه: خانو اده اساسى ترين نهاد اجتماعى زمينه ساز جوامع و تاريخ بشر است. طلاق يكى از مباحث اجتماعى است كه اغلب براى

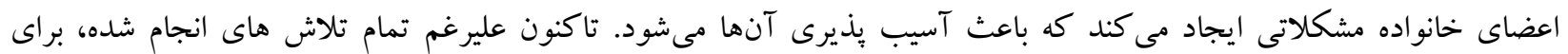

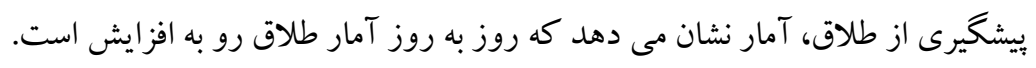
هدف: هدف تحقيق حاضر فراهم كردن جارجوبى براى رهيارى پـ از طلاق است. نتايج در سه قسمت تقسيم بندى شده است.

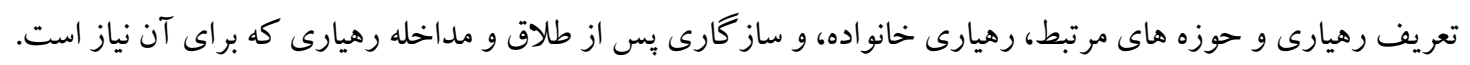
روش: مطالعه حاضر توصيفى تحليلى (از نوع مرورى) است كه به بررسى جامع يُزوهش هاى صورت گرفته در حوزه رهيارى يرداخته

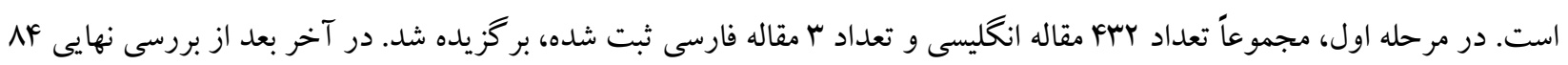
مقاله از اين مقالات انتخاب شدند.

يافتها: از آنجايى كه تحقيقات در رهيارى بسيار محدود است، هيج سابقه اى براى مداخلات رهيارى در ارتقا زندگى افراد مطلقه در

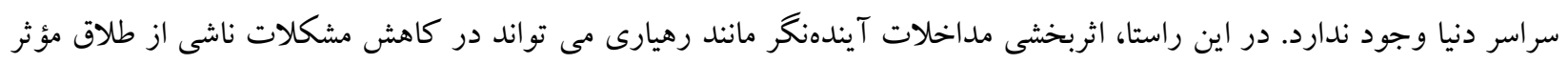

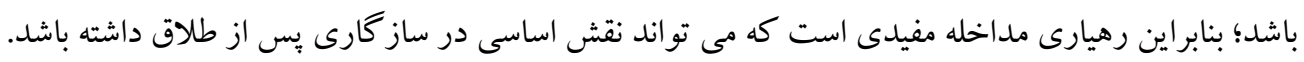
نتيجه گيرى: اخرجه طلاق براى اعضاى درگير آن عواقبى به دنبال دارد، مداخله رهيارى بـ از طلاق مى تواند كيفيت زندگى طلاق

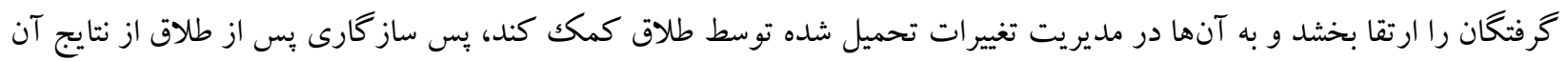
خواهد بود. كليد وازهها: رهيارى بِ از طلاق، رهيارى طلاق، كوجينگك پٍ از طلاق، ساز كَارى بِ از طلاق 


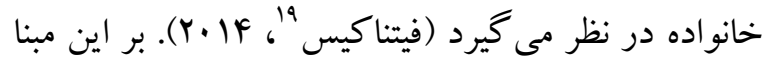

مقدمه

تغيير از جهت گيرى آسيب شناسى طلاق به تمركز بر

بهرغم اين كه طلاق، مرحله گذار رايجى شده است، اين تاب آورى و ارتقا بهزيستى روانشناختى منجر به استفاده

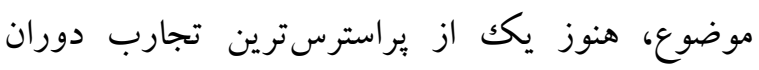
از مداخلات مثبت و قدرت محور مانند روانشناسى

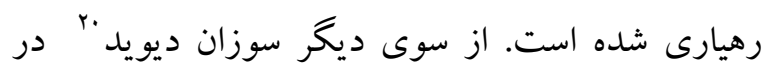

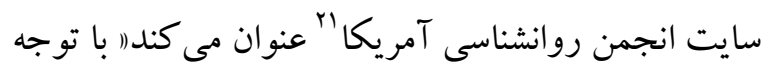

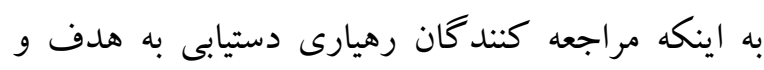
افزايش رضايتمندى از زندكى را از نتايج رهيارى كزارش كردهاند به يزوهشهاى در اين زمينه نياز است.

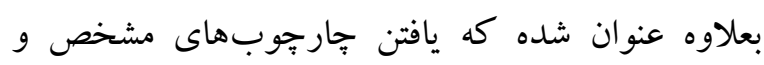
نحوه مداخله در حيطه وظايف محققان حوزههاى مشاوره

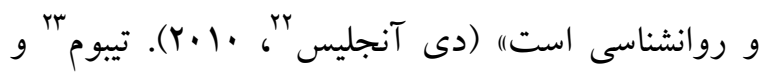
همكاران در يكك فرا تحليل در سال rا •r علاوه بر اينكه رهيارى را به عنوان ابزار مفيدى معرفى مى كنتد كه به

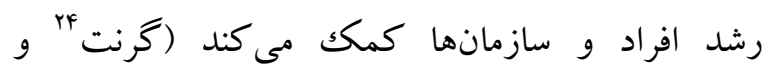
همكاران، · (Y. )، به كمبود تحقيقات نظرى و تجربى در

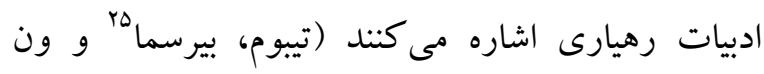

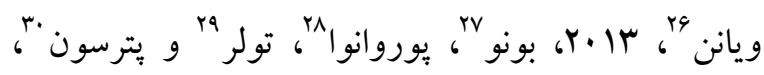

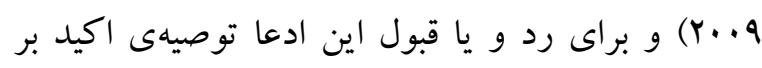
مفهوم يردازى و ساختن بايههاى اين مداخله و تحقيقات كاربردى در اين زمينه مى كنند. از سوى ديخر با وجود ئرد تبليغاتى كه در مجلات و در سراسر اينترنت جهت رهيارى طلاق ديده مىشود، در هيجيك از مقالات و

19- Fthenakis

20- Susan David

${ }^{21}$ - American psychological association (APA)

22 - DeAngelis

23. Theeboom

${ }^{24}$ - Parker

25 - Beersma

26- Van Vianen

27- Bono

28 - Purvanova

${ }^{29}$ - Towler

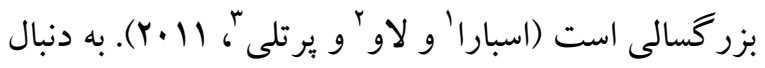
فروياشى زناشويى، بزرگسالان، ناراحتى روانشناختى و نشانهاى استرس بِ از سانحهاى را نشان مىدهند كه

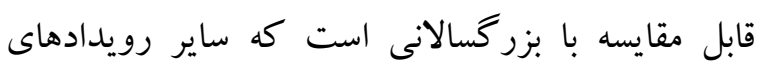

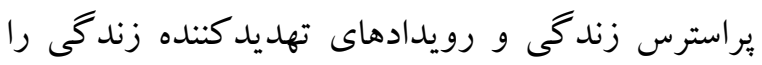

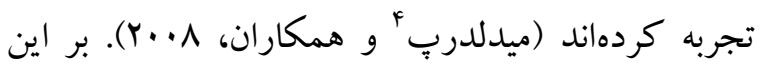
اساس بزرگسالانى كه طلاق گرفتهاند، در مقايسه با بزركسالانى كه ازدواج كردهاند، ميزان بالاترى از بريشانى روانشناختى و نيز نشانهاى افسردگى و ولى

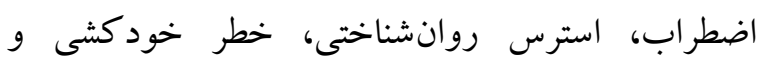
مشكلات جسمانى بيشترى را كزارش مى كنند (آربرهّو

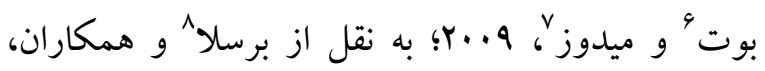

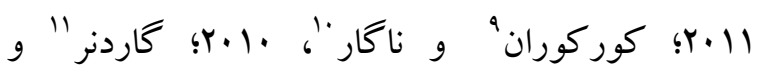

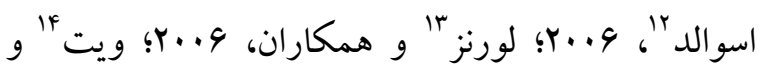

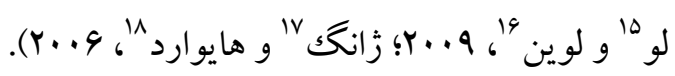
اخيراً رويكرد تحول خانواده و جشم انداز تابن آورى بديده طلاق را به عنوان مرحله گذار در روند رشد

\footnotetext{
1. Sbarra

2 - Law

3 - Portley

4- Middeldorp

5 - Arber

${ }^{6}$ - Bote

7. Meadows

8 - Breslau

9 - Nagar

${ }^{10}$ - Corcoran

${ }^{11}$ - Gardner

12 - Oswald

${ }^{13}$ - Lorenz

14- Waite

${ }^{15}$ - Luo

16. Lewin

${ }^{17}$ - Zhang

${ }^{18}$ - Hayward
} 
و روانشناسى رهيارى نيز به سرعت در حال رشد است

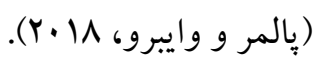

در حالى كه متون رهيارى همجنان در حال رشد است، صنعت رهيارى نيز به رشد خود ادامه مى دهد. از سال . 191 تا سال 1997، حوز0ى رهيارى به انواع حوزههاى ديخرى بسيار فراتر از ورزش و كسب و كار توسعه يافته است و شروع به دستيابى موفقيتهايى در زندكى، سلامت و عرصه خانواده كرده است (هادسون؛، 1999). هر ساله تعداد مقالات رهيارى در هر يكك از اين رشته ها نيز به رشد خود ادامه مى دهند. ماهيت رهيارى، جه اجرايى و جه رهيارى زندگى، تغييرات در سطوح عاطفى، شناختى و رفتارى را حفظ به نمايش مى كذارند

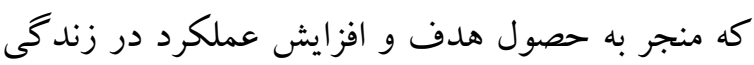

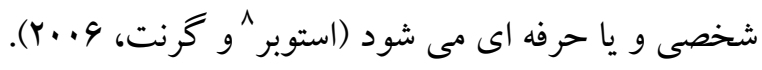

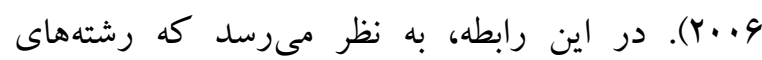
رهيارى و روانشناسى رهيارى در مسير رشد ادامه خواهند

داد.

بسيارى از تحقيقات نشان مى دهند كه مراجعه كنند كانى كه از خدمات رهيارى استفاده كردهاند ارتقاء يافتهاند. البته ممكن است برخى نواقص در برخى شواهد وجود

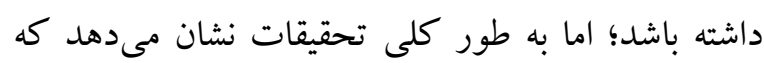
روانشناسى رهيارى مؤثر است. روانشناسى رهيارى براى تقويت بهزيستى و عملكرد در حوزههاى زندكى فردى و حرفهاى است كه مدلهاى رهيارى با نظريه هاى يادگيرى و رويكردهاى روانشناسى يشتيبانى مى شوند (كرنت و وهرئ

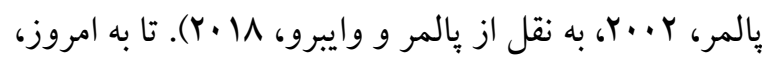

7 - Hudson

${ }^{8}$ - Stober
كتابهاى موجود شواهدى مبتنى بر نحوه مداخله و تأثيرات آن بر جامعه طلاق ديده نمىشود. بر اين اساس ضمن اينكه طلاق در جامعهى ما تبديل به بحرانى اجتماعى شده و توصيههاى فراوانى جهت برنامههاى بيشخيرانه شده است و از سوى ديخر جون در ميان ديخر نظريههاى خود تنظيمى' ' رهيارى فلسفهى منحصر به فرد خود را دارد كه ارزش كشف و بررسى دارد (فاضل،

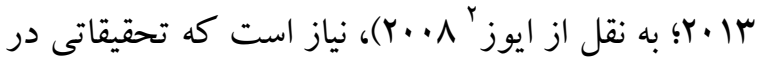
داخل ايران در زمينهى روانشناسى رهيارى انجام شود.

\section{بيشينه يزوهشها} با وجود اينكه روانشناسى رهيارى رويكردى نسبتاً جديد در زمينه خدمات روانشناسى است، متون رهيارى به سال

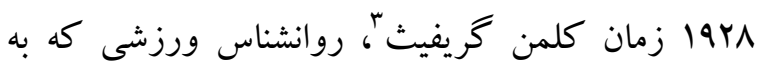

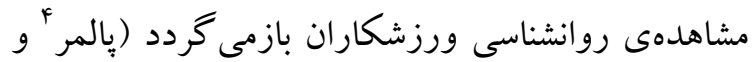

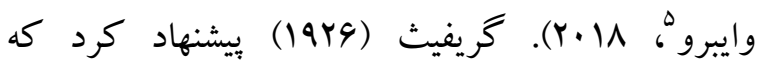
رهيارى بيش از آموزش دادن است. در حالى كه حوزهى مربيخرى ورزشى به مدت طولانى با حوزه رهيارى همراه بوده است، حوزه كسب و كار رهيارى خيلى عقب نمانده

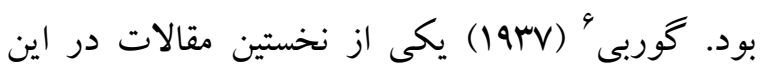
زمينه را نوشت؛ وى دقيق بيان كرد كه جِكونه تكنيك هاى رهيارى را مى توان براى افزايش بهرهورى و سود در كسب و كار به كار گرفت. تمر كز برجسته متون رهيارى در صنعت كسب و كار، قسمت اعظم متون رهيارى قرن

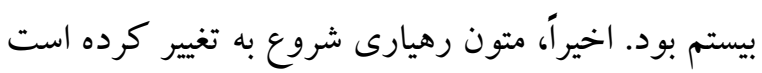

\footnotetext{
1 - Self-regulatory

2- Ives

3 - Griffith

4- Palmer

5- Whybrow
}

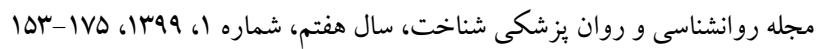


هدفمند، خودمختارى و رشد فردى نيز تغييرات معنى

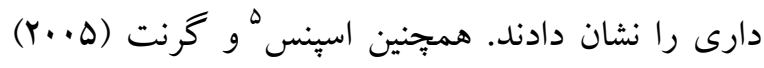
دريافتند كه رهيارى به ارتقا دستيابى به هدف، رضايت از زندگى و رشد فاكتورهاى كنترل محيطى و نتايج شخرفى در باز بودن به تجربه كمكك نمايد. بعلاوه رهيارى زندكى

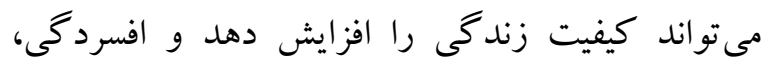
اضطراب و استرس را كاهش دهد. كميل "و و كاردنر

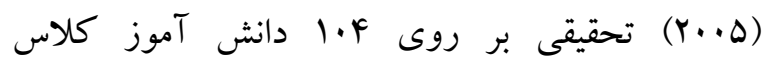
دوازدهم انجام دادند. دانش آموزانى كه در اين تحقيق رهيارى شدند توانايى مديريت روابط خود را بيشتر از قبل

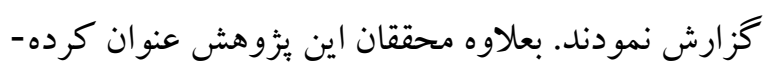
اند كه رهيارى مىتواند يتانسيل ساختن تابآورى و بهزيستى را داشته باشد و به دانش آموزان كمكك مى كند كه با استرسزاهاى زندگى مقابله نمايند. تحقيقات گرين،

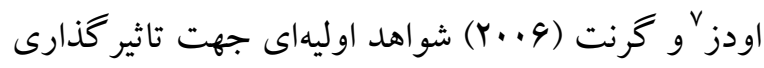
تاثير گذارى رهيارى مبتنى بر شواهد تهيه كردهاند. اين تحقيقات كه بركرفته از حوزه روانشناسى رهيارى است نشان داده است كه رهيارى زندگى مبتنى بر شواهد مى -

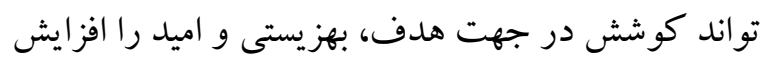
دهند. آنها در تحقيقى كه بر روى 9ه نفر نشان دادند كه رهيارى رفتارى شناختى راهحل محور به طور قابل ملاحظه ایى در بهزيستى روانشناختى گروه كنترل داشته و تمام زير مقياسهاى بهزيستى روانشناختى رشد

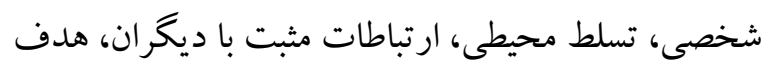

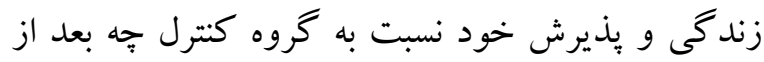

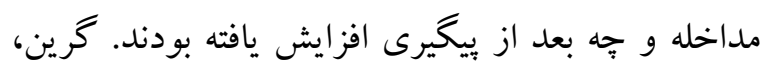

بسيارى از تحقيقات نشان مى دهند كه مراجعه كنند كانى كه از خدمات رهيارى استفاده كردهاند، ارتقاء يافتهاند. روانشناسى رهيارى به عنوان اصول كاربردى روانشناسى

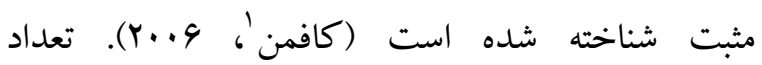
مداخلات روانشناسى مثبت در حال افزايش است و در

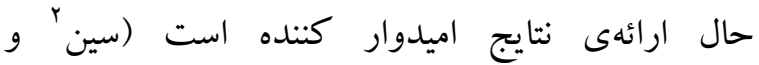

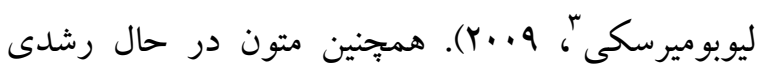
درباره كارآمدى مداخلات مثبت روانشناسى رهيارى خاص كه باعث افزايش بهزيستى مىشوند، وجود دارد

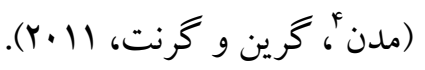

اولين تحقيق تجربى كه رهيارى را خارج از حوزمى كسبو كار بررسى كرده مربوط به كار گرنت (r... است كه بر روى ها دانشجو انجام داد و رهيارى را در دستيابى به هدف و بهزيستى مؤثر نشان داد. وى در تحقيق خود نشان داد كه رهيارى كاهش معنى دارى در استرس، اضطراب و افسردگى نيز داشت. وى با اينكه در تحقيق خود كيفيت زندگى و سلامت روان را هدف قرار نداده بود ولى دريافت كه رهيارى موجب افزايش آنها مى -

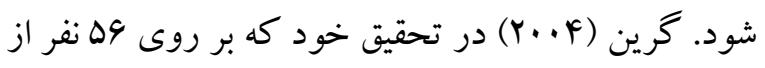
جامعهى غير بالينى انتخاب كرده بود و در دو كرودين

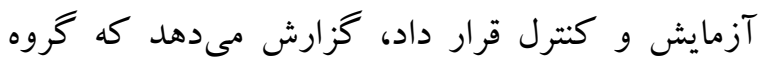
آزمايش در دستيابى به هدف، اميد، احساسات مثبت، بهزيستى روانشناختى و بهزيستى ذهنى تغييرات بيشترى

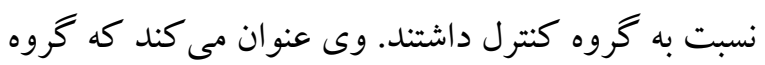
آزمايش در زيرمقياسهاى بهزيستى روانشناختى بذيرش

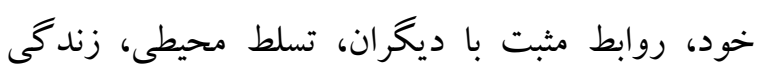

5- Spence

${ }^{6}$ - Campbell

7. Oades
1- Kauffman
2- Sin
3- Lyubomirsky
4- Madden 


\section{ووش}

به منظور بررسى همه جانبه بثزوهش هاى صورت بذيرفته

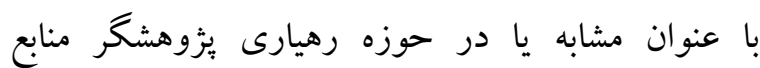
متعددى را مورد بررسى قرار داده است. در اين راستا علاوه بر بررسى منابع اطلاعاتى خارجى كه در ذيل به به بـ

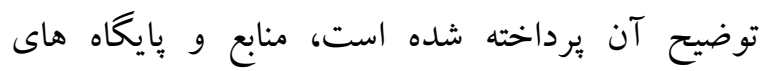
اطلاعاتى داخل ايران نيز مورد بررسى قرار گرفته است. مدالين داراى بيش به ميليون منبع مربوط به مقالات مجله اى از سال • بهوا تاكنون است كه بيشتر آنها در ايالت

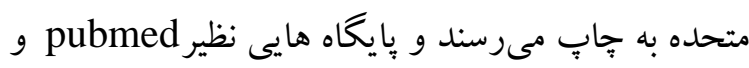
Ebsco مى باشند. ام بيس نيز شامل بيش از اY ميليون مداركك به ثبت رسيده از سال 19FV تا اكنون است و هر ساله بيش از يكك ميليون سند به آن افزوده مى شود. اين بايگاه

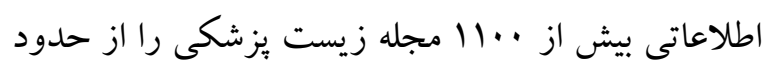

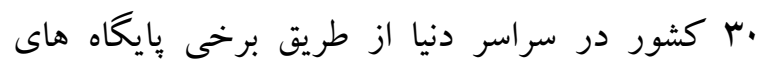
اطلاعاتى نظير Olsevier و Ovid در اختيار كاربران قرار مى دهد. از آنجايى كه انجام يك جستجوى جامع براى شناسايى حداكثر مطالعات قابل بازيابى موجب به

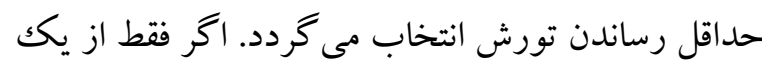
موتور جستجو استفاده شود، كافى نيست، زيرا بررسى ها

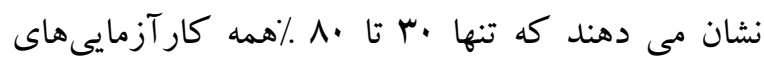
بالينى تصادفى شده از طريق مدالين قابل شناسايى هستند.

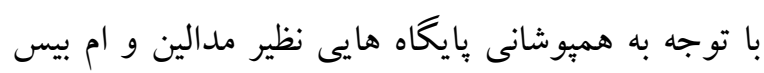

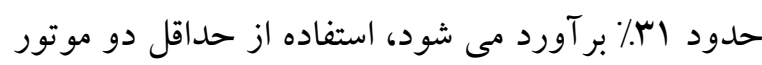

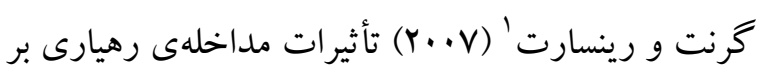
اميد و سخترويى شناختى را در تحقيقات خود معنى دار

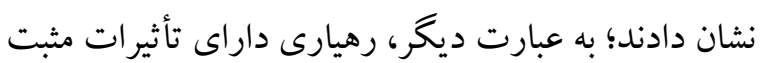
بر كيفيت كلى زندگى شركت كنندگان است. بعلاوه

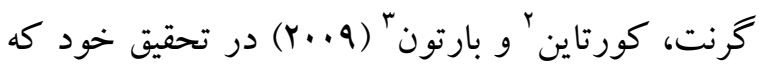
رهيارى را براى أF مدير اجرايى بكار برده بودند دستيابى بورئ به هدف، افزايش بهزيستى شغلى، افزايش تاب آورى و كاهش استرس و اضطراب را گزارش داده اند. تيبوم و همكاران در يك فرا تحليل كه از نتايج رهيارى تكميل كردهاند دريافتند كه اثربخشى ينج كروه نتيجه سطح فردى را بررسى كردهاند: عملكرد، بهزيستى، مقابله،

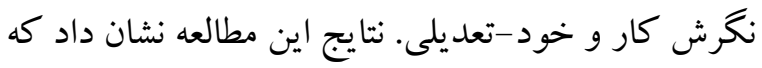
رهيارى، در واقع، اثرات مثبت قابل توجهى بر همه ينج نتيجه دارد. افرادى كه از رهيارى استفاده كرده اند، تابآورترند، بهزيستى بيشترى دارند، بينش آنها افزايش يافته است و احتمال بيشترى دارد كه به اهداف خود برسند

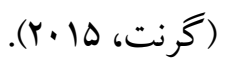

يثزوهش در روانشناسى رهيارى جوان است و ما شواهدى داريم كه رهيارى به خوبى كار مى كند. با اين حال ما هنوز هم بايد راه طولانى را طى كنيم تا به واقع درك

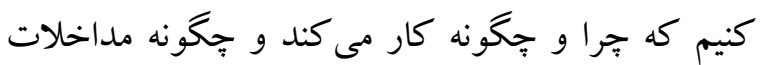
رهيارى به طور مؤثر كار مى كنند. يُوهش هاى بيشتر به به

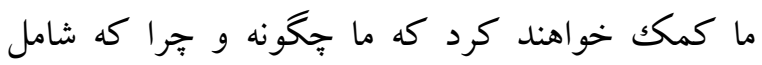

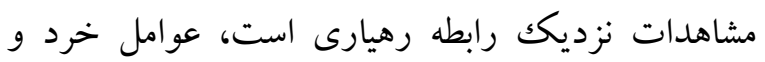

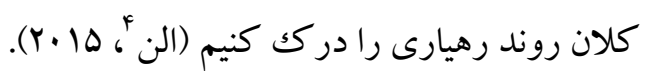




\section{رهيارى جيست}

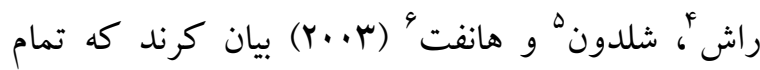
تعاملات رهيارى سه مشخصهى ويزه دارند () خوديابى Y) تمر كز بر عملكرد معنىدار و ب) جهت گيرى فرايند. روانشناسى رهيارى يكك رشته جديد است كه زمينه هاى نظرى غنى و متفاوت را در كنار هم قرار مى دهد تا يكك رويكرد برتكايو و مبتنى بر شواهد ارائه دهد كه به مردم

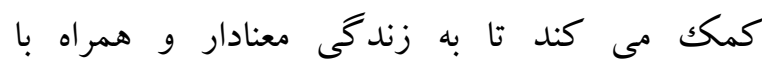
رضايتمندى برسند.

فدراسيون بين المللى رهيارى اولين سازمان جهانى رهيارى، رهيارى را اين گونه تعريف مى كند: (رهيارى حرفه اى يك رابطه حرفه اى رو به جلو مى باشد كه به مردم كمكك مى كند تا نتايج شخفت انكيزى در زندگىى، مشاغل، كسب و كار يا سازمان هاى خود توليد كنند. از طريق فرايند رهيارى، مراجعه كنند گان بادگيرى خود را عمق مى بخشند، عملكرد خود را بهبود مى بخشند و

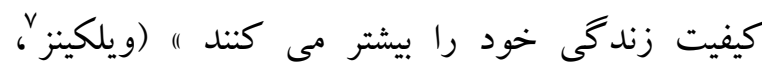
( $($. $\cdots$

هادسون (1999) تعريف ديخرى ارائه مىدهد كه شامل اطلاعات جزئىترى درباره فرايند رهيارى است. رهيار شخصى است كه ياد گيرى تجربى را تسهيل مى كند به طورى كه منجر به توانايى هاى معطوف به آينده مى شود. وى مى گويد "ارهيار فردى آموزش ديده است و خودش هوري را وقف راهنمايى ديخران به سمت افزايش شايستخى، ورئ تعهد و اعتماد به نفس، مى كند) (هادسون، 1999).

${ }^{4}$ - Rush

5- Shelden

${ }^{6}$ - Hanft

7. Wilkins
جستجو براى اطمينان از نتايج جامع لازم است (كرين' و

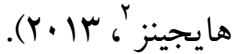

در انجام يُزوهش حاضر از سه بِيڤاه اطلاعاتى خارجى به نام هاى مدالين، ام بيس و ساينس دايركت استفاده شد. علاوه بر جستجوى مقالات منتشر شده در زورنالهاى داورى شده ممكن است، لازم باشد جستجوهاى دستى و اينترنتى، رديابى مراجع موجود جهت دستيابى به مقالات بيشتر و ارزيابى زورنالهاى مرتبط نيز صورت گيرد. اكرجه ممكن است مرورهاى توصيفى، خلاصه مقالات كنفرانسها و كتب مرجع از فرايند كار مربوط به استخراج شواهد و داده ها كنار كذاشته شوند، ليكن مىبايست مورد توجه قرار گيرند، زيرا مى توانند شامل اطلاعاتى براى كشف منابع مربوط به مطالعات اصلى قابل

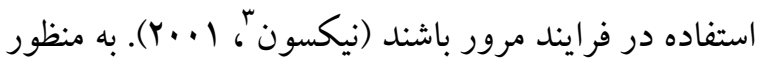
تحقق اين هدف و براى جستجوى مقالات فارسى علاوه بر جستجو در گو گل اسكولار در بايگًاه جهاد دانشگاهى SID مرور بر مطالعات انجام شده را با كليدوازه هاى

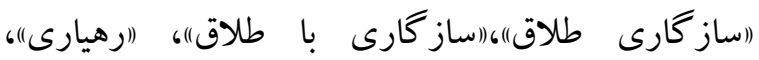

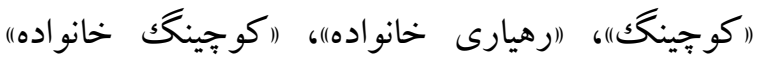

$$
\text { مورد بررسى قرار داد. }
$$

مطالعه حاضر توصيفى تحليلى (از نوع مرورى) است. بهمنظور بررسى جامع بُزوهشهاى صورت يذيرفته در حوزه رهيارى برداخته است. نتيجه بررسىهاى صورت كرفته، در كل تعداد سY Fr مقاله انخليسى و تعداد ب مقاله فارسى ثبت شده، ذخيره گرديد. بعد از بررسى نهايى در نهايت تعداد NFمقاله انخُليسى مرور شد.
1- Green
2- Higgins
3 - Nicholson 


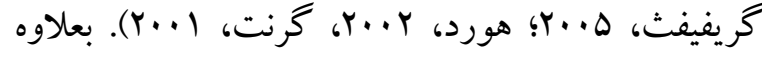

رهيار نياز ندارد در حوزهى يادگيرى مراجع متخصص باشد و نكتهى جالب دربارهى رهيارى اين است كه رهيار نشان دهد كه متخصص نيست بلكه كنجكاو و مشتاق

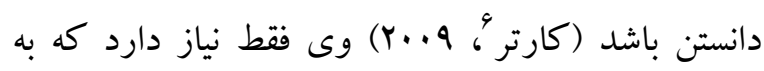

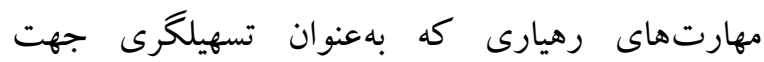
يادگيرى و ارتقا عملكرد است، تخصص داشته باشد

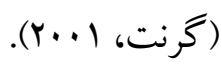

\section{ז. رويكرد راهحل محور است}

تمركز رهيارى به جاى تحليل مشكلات بر ساختن

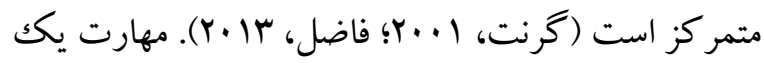
رهيار اين است كه بتواند مشكل رابه صورتى تغيير شكل دهد كه قابل حل به نظر برسد و همزمان كه ارتباطى

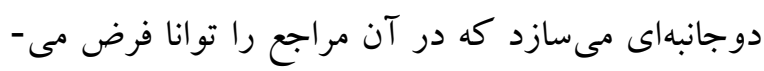

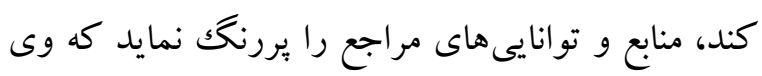
بتو اند قدمهاى مؤثر ايجاد نمايد (كرنت، و 9. ب).

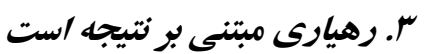

بلدون اقدام عملى هيج بازخورد و تجربهاى وجود ندارد كه بتوان انعكاس اقدامات را سنجيد در نتيجه فرايند رهيارى بى معنى خواهد بود. رهياران هميشه از مراجع سوا لاتى مى يرسند كه بتوان قدمهاى مؤثر قابل بحثى را در حين جلسات تعريف كنند. در آخر هر جلسه مراجع بايد متعهد به تكليفى كه در جلسه تعريف كرده باشد كه بتواند بر تكليف و نتيجهى آن اتكا نمود. ع. رهيارى فراينلسى سيستماتيك /ست

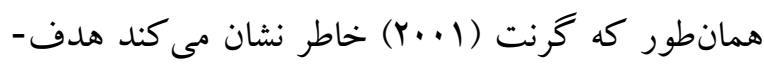
كذارى جرخهى رهيارى را راه اندازى مى كند كه اين

4- Kimsey-House

5 - Sandahl

${ }^{6}$ - Carter
اين تعاريف جنبه هاى مشترك زيادى با هم دارند جرا كه همه آن ها به رهيارى به عنوان يك فرايند با هدف نهايى

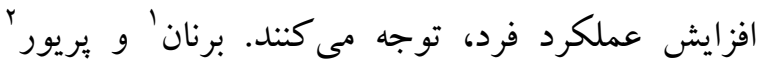

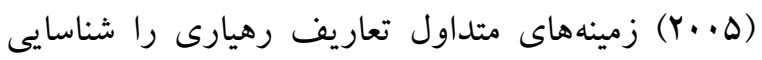
كردند. اين زمينه ها شامل يكك رابطه برابرنخر، تمر كز بر راه حل و رسيدن به هدف و نيازمند قابليت هايى براى تسهيل يادگيرى و رشد، مىباشند. رهيارى مؤثر به جاى اينكه به مراجع بـويد جهه كارى بايد انجام دهد با برسيدن سؤالات درست موجب تسهيل رشد مىشود (استوبر و كرنت، 9. بهترين تعريفى كه از رهيارى تا به حال ارائه شده توسط

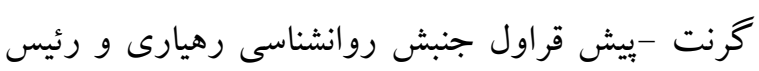

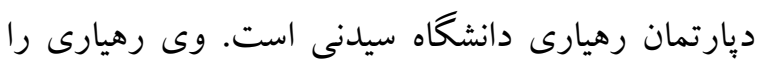
اين گونه تعريف مى كند: "رهيارى فرايندى دوجانبه راه حل محور، سيستماتيك و نتيجه گراست كه در آن رهيار تسهيلكر ارتقا تجربيات زندگى و دستيابى به هدف درون در زندكى شخصى و تخصصى در افراد نرمال و غير بالينى است كه رهيار ارتقا تجربيات زندگى و عملكرد مراجع را در دامنههاى مختلف زندگى تسهيل مى كند كه در آن ياد گيرى خودمحور، رشد شخصى و دستيابى به هدف را دار

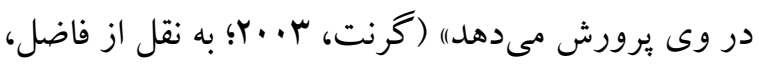
.$(r \cdot 1)$ ا.رهيارى ارتباطى دو جانبه است

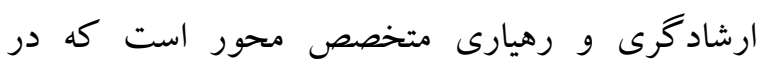
رهيارى جֶه در متون تجربى و جه تكنيكال تأكيد بر ارتباطى دوجانبه و همتراز بين مراجع و رهيار است

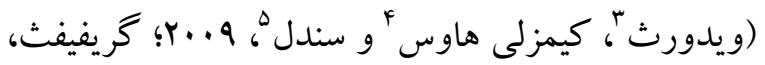

1- Brennan
2- Prior
3- Whitworth 
است كه دستيابى به هدف و ارتقا عملكرد را تسهيل مى - كى إهورا كند. بعلاوه ويتمور (1994) عنوان مى كند كه رهيارى

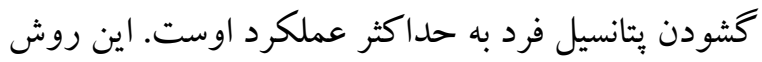
به آنها كمكك مى كند تا به جاى اين كه آموزش ببينند، ياد بحيرد. همانطور كه بيش از اين اشاره شد در رهيارى بيش از اين كه متخصص محور باشد بر رابطهاى دوجانبه

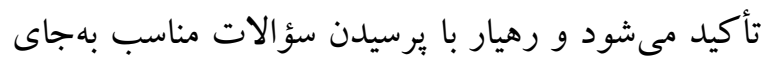
جواب دادن به فرد كمك مى كند كه روش و عملكرد خود را ارزيابى كند و نه تنها بهترين تصميم را بخيرد بلكه خود عامل ايجاد تجربيات جديد در زندگى شود.

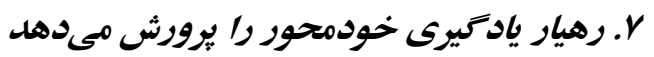
رهيارى رويكردى است كه با در نظر گرفتن جنبه رهاى شناختى و رفتارى يادگيرى (فاضل، با.بr) از نظريات ياد گيرى كمك مى گيرد تا بتواند ياد گيرى تجربى را كه بر اساس عملكرد خود فرد شكل كرفته ارتقا دهد. در اين روند رهيار از نظريههاى مختلف ياد كيرى بهصورت

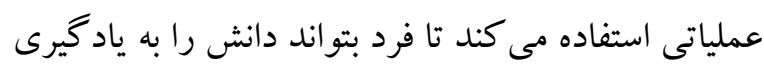

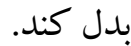
1. رهيار رشد شخصى را ارتنقا ميبخشل حر كت به سمت يكك هدف از طريق يكك فرايند حمايت رهار كننده جوهره روانشناسى رهيارى است. در فر ايند رهيارى تمركز بر اين است كه مراجعه فاصله بين آنجه كه هست و آنجه كه مىخواهد باشد را به حداقل برساند بر اين اساس به مدد روانشناسى انسان كرايانه، روانشناسى رهيارى در حركت مشتاقانه در جهت رشد متمركز است

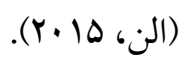

\section{9.رهيارى دستيابى به هدف را تسهيل ميى كند}

در تمام متون رهيارى انتخاب هدف جزء لهئ لاينفك رهيارى بشمار مىرود و فلسفهى رهيارى تمركز اصلى بر انتخاب هدف و ساختن مسير به سمت رسيدن به هدف
جرخه با اقدام متمركز و برنامهريزى شده به سمت هدف دنبال مىشود. در هر جلسه رهيار به مراجع كمك مى كند كه اين هدف مىتواند هدفى درونى جون مديريت هيجان، ارتقا شهود، شناسايى ترجيحات شخصى باشد و يا هدفى بيرونى جون تعريف رسالت، اولويتبندى اقدامات، يافتن راههاى جديد باشد كه رسيدن به هدف اصلى را تسهيل مى كند. رهيار در اين مقطع روشهاى مختلفى را براى مشاهده، تمرين و تحليل براى ارزيابى

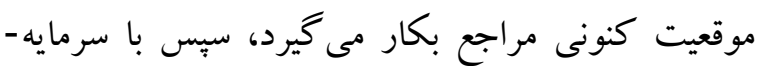

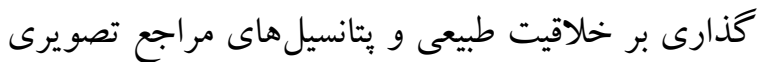
بزرگكتر از آينده براى وى ايجاد مىنمايد. نهايتاً حفظ شرايط موجود، حمايت از بنيانها و تحولات ساختارى و بازخوردها جرخهى رهيارى كامل مىشود (كريفيفث، $(Y+\Delta$

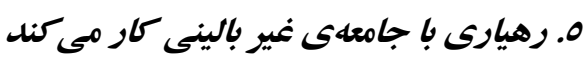
بحث هاى زيادى در اين زمينه شده كه رهياران نياز به به بهان مهارتهاى تشخيصى ندارند و جنين جامعهاى را بايد به متخصصان اين حوزه - روانشناسان و روانيزشكان سبرد. تمركز بر جامعهى غير بالينى تفاوت بين روان

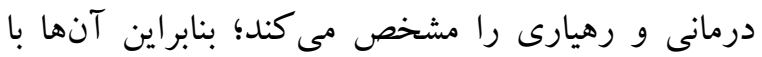
جامعهى غير بالينى كار مى كنند و مر اجعينى كه مشكلات بالينى دارند را بايد به روانشناسان بالينى ارجاع دهند جون

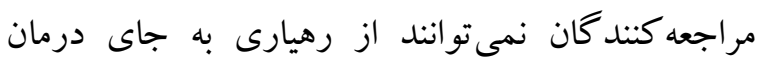

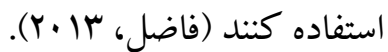

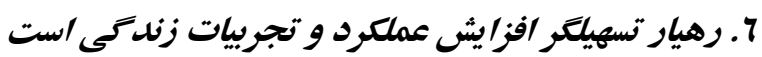

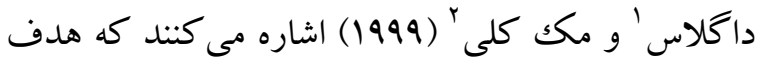

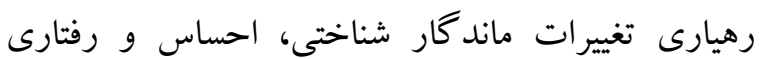

\footnotetext{
- Douglas

2- McCauley
} 
است. رهياران خانواده تلاش مى كنند با استفاده از تكنيك ها و مدل هاى رهيارى، ارتباط دوجانبهاى بين رهيار و مراجعه كنند گان ايجاد كنند كه بتواند رِشتيبانى لازم را ارائه دهند و فرصت هاى رشد را يرورش دهند. رهياران خانواده در تلاش هستند كه ظرفيت اعضاى خانواده را در جهت ارتقاء توانايى ها و مهارت ها توسعه دهند (راش، شلدن و هانفت، ب...Y). رهياران خانو اده از شيوههايى مانند سؤال قدرتمند (مثلاً سؤال، مقايسه)، ارائه بازخورد، انجام ارزيابى (به عنوان مثال، نقاط قوت،

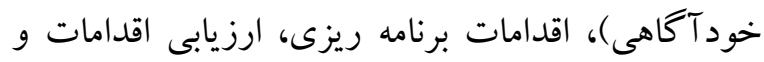
ارائه بِاخخگويى در تعاملات غيرقانونى استفاده مى كنند

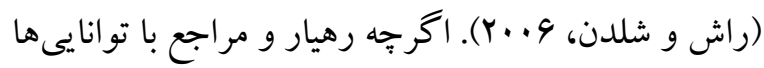
و نقشهاى مختلف در جلسه حضور بيدا مى كنند و هر گز كاملاً برابر نيستند، تأكيد مداوم بر ايجاد رابطه برابرى در جايى كه قدرت در آن مشترك است، تأكيد

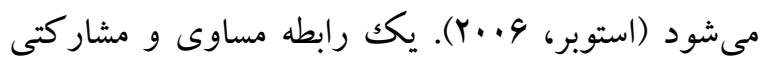
تعامل و منافع مثبت را براى مراجع تسهيل مى كند (ايو،

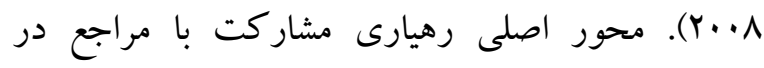
رسيدن به اهداف و آرزوهايى است كه براى خودش انتخاب مى كند (كرنت و كاواناگى، V. . . (Y). به طور كلى مىتوان كفت رهيارى خانواده يكك رويكرد فرد محور است كه در رويكردهاى نظرى و بالينى

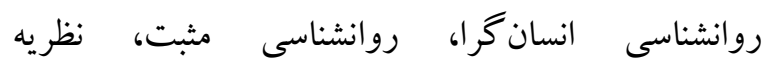
اكولوزيكى و نظريه سيستم هاى خانو اده گسترش مى يابد؛ بنابراين، رهياران خانواده نياز به دركك نظرى و عملى از علم خانو اده و شيوه هاى مبتنى بر شواهد از جمله رشد و ييشرفت انسان، سلامت روان، آموزش ارتباطات و فرزند يرورى دارند.
مذكور است. جرا كه رهياران با افرادى كه اهداف و يا

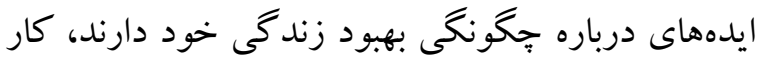
مى كنند. رهيار ان زندگى با مراجعه كنند كان كار مى كنند تا به آن ها در رسيدن به اهداف شناسايى شده توسط خودِ

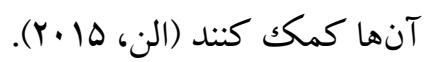

\section{رهيارى خانواده}

اگرجه خانواده درمانكران در كار خود كاهيى از فرايند رهيارى استفاده مى كنند، ولى در تحقيقات نظرى و تجربى درباره رهيارى خانواده، شكافى عميق وجود دارد

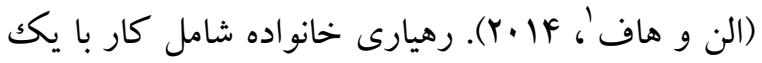
فرد، زوج يا خانواده براى رسيدگى به مسائل مربوط به خانواده از طريق فرآيند رهيارى است (الن، هابـب). رهيارى خانواده مراجعه كنند گان را به سمت(|فزايش

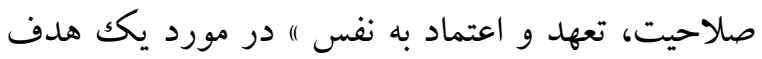
مشخص هدايت مى كند (هادسون، 1999). رهيارى خانواده بهطور كسترده يكك رابطه فرايند محور بين سيستم خانواده و رهيار است كه براى تقويت اهداف خانواده مشخص شده است. رهيار خانواده ممكن است با بيش از يكك عضو خانو اده همكارى كنند، اما به احتمال زياد يك لك رهيار خانواده با يكك فرد، والدين يا زوج در مسائل مربوط به زندكى خانو اده همكارى خو اهد كرد. برخلاف آموزش زندكى خانوادكى بُ كه از مجموعه ایى از مطالب مانند برنامه درسى يا يكك برنامه آموزشى

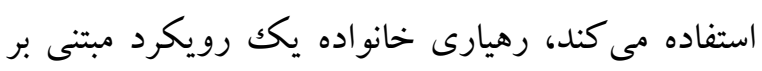
نقاط قوت براى كمكك به خانو اده ها در رسيدن به اهداف

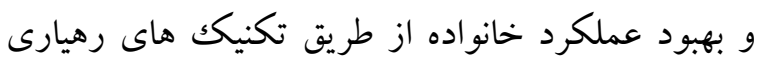

\footnotetext{
1. Huff

2- Family Life Education
} 


\section{بنياد نظرى رهيارى خانواده}

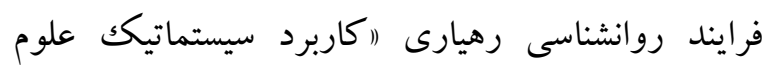

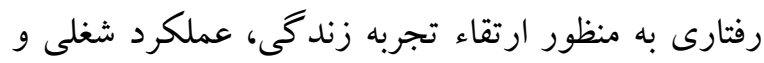

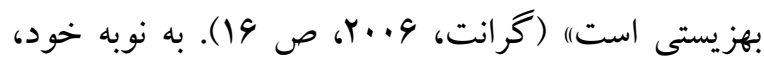
حوزه روانشناسى رهيارى هنوز در حال شكل گيرى است. تعريف روانشناسى رهيارى همانطور كه توسط انجمن

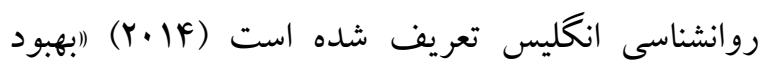
بهزيستى و عملكرد در زندكى شخصى و حوزهاى كارى است كه توسط مدل هاى رهيارى مبتنى بر عربى ياد گيرى بزرگكسالان يا ديخر رويكردهاى روانشناختى مهنى

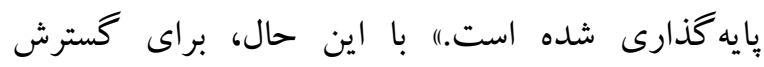

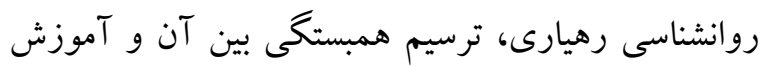

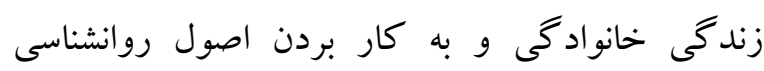
رهيارى در زمينه هاى خانو اد گى است. زيربناى نظرى روانشناسى رهيارى از روانشناسى انسانگر

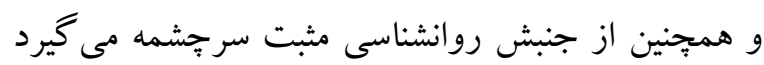

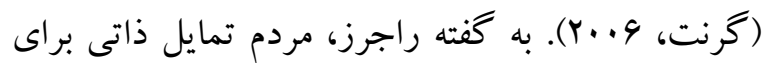
بيشرفت به سمت سلامتى و عملكرد يا (واقعى سازى)"

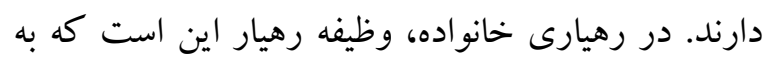
مراجعه كنند كان كمكك كند تا با استفاده از تكنيك هاى رهيارى مانند استفاده از سؤالات قدرتمند، تكاليف

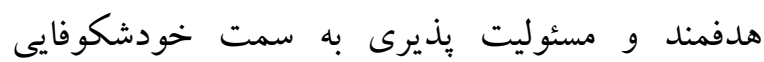
حركت كنند. هانفت، راش و شلدن (Y..F) ينج مورد ضرورى را در رهيارى خانواده مشخص كردند: (الف) رابطه مشتركك بين رهيار و مراجع، (ب) بازخورد دادن و استفاده از سؤال، (ج) مشاهدات و اقدامات متقابل، (د) تمركز بر عملكرد و (ه) روندى فر آيند محور كه توسط مراجع تعيين مىشود. به طور خاص، رهياران با يرسيدن

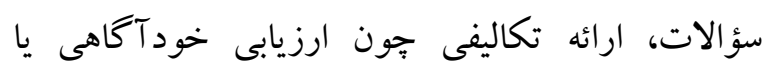

نقش رهيار خانواده جند وجهى است، به طورى كه بسيارى از متخصصان اين حرفه در مورد موضوعات مربوط به خانواده مانند فرزند يرورى، روابط زوجين،

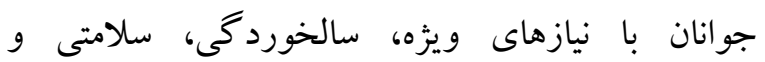
شاد كامى، مديريت مالى خدمات ارائه مىدهند.

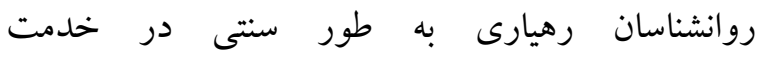
مر اجعه كنند كانى كار آمد بودند كه مى خو استند به اهداف

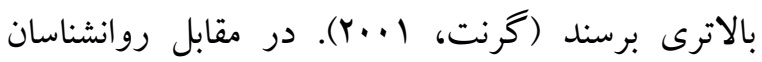
بالينى و مشاورهاى است كه به افرادى كه نيازهاى روانى

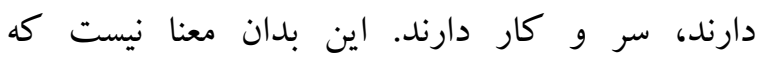
خانوادههاى داراى فشار روانى نمىتوانند از رهيارى خانواده بهرهمند شوند. تكنيكك هاى رهيارى در مداخلات و همجنين خدمات بيشخيرى استفاده مى شود (الن، ها ·Y). به عنوان مثال، ارائه دهند گان خدمات درمانى در منزل از رهيارى با خانوادههاى در معرض خطر و يا نياز

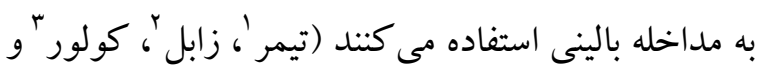

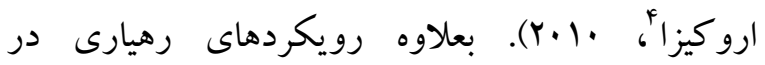
حرفهاى مددكارى اجتماعى نيز مورد استفاده قرار مى گيرد كه از رهيارى با خانو ادههايى كه نياز به مداخله

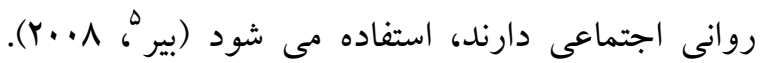
علاوه بر اين، در كودكانى كه داراى تأخير در رشد هستند، از يكك روند مداخله رهيارى استفاده مى بود كه خانوادهها با استفاده از رهيارى بتو انند با كود كانشان بهتر تعامل كنند (راش و همكاران، r...r).

\footnotetext{
1. Timmer

${ }^{2}$ - Zebell

3 - Culver

4- Urquiza

5 - Beyer
} 
شود، اما اين مقالات يكك بررسى نظرى يا توضيحى عملياتى از رهيارى ارائه نمىدهند. اصطلاح رهيارى بيشتر براى توصيف روند كار يكك به يكك به منظور كمكك به مراجع در ايجاد تغيير و بهبود مهارتهاى ارتباطى در هر يكك از حوزههاى ياد شده بكار مىرود. آنجه به خوبى در تحقيقات ذكر شده نشان داده مىشود اين است كه رهيارى در حوزه طلاق نه تنها هنوز جه از نظر پايههاى نظرى و جهه در تحقيقات مبتى بر شواهد و كاربردى مورد توجه قرار نخر فتهاست. بر اين اساس در

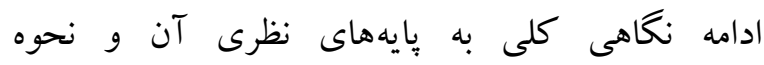
به كار گيرى رهيارى يس از طلاق مى يردازيم.

\section{ساز كارى با طلاق}

ساز گارى بِ از طلاق در طول ساليانى كه اين متغير به ادبيات روانشناسى وارد شده است، بهطور تغييراتى كرده اسـت. گودى (1990) ساز كارى پس از طلاق را تلفيقى از تجارب بِ از طلاق مىداند كه فرد رانه به عنوان هويتى كه در رابطه زوج قبلى خود داشته، بلكه به عنوان موقعيت كنونى او كه هر روزه با آن سر و كار دارد تعريف مىنمايد. وايزمن (I9VD) اعتقاد دارد وقتى فرد به قبول كامل فر آيند طلاق دست يابد، ديخر با هويت يابى خود به عنوان فردى مطلقه، عواقب منفى آن را تجربه نخواهد كرد. وايزمن (19VD) بر اين باور است كه فردى

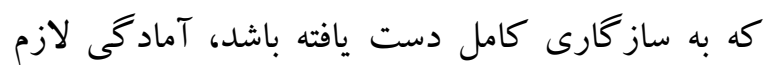
براى رابطهاى سالم و صميمى را خواهد داشت. برخى ديخر از محققين و متخصصين بر اين عقيدهاند كه

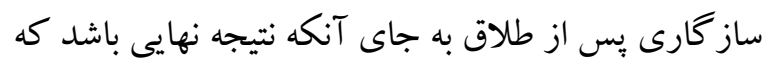

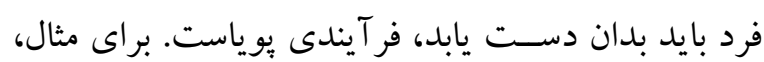

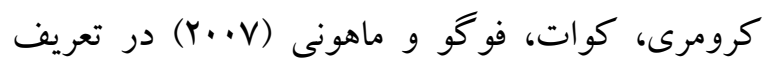
ساز گارى بِ از طلاق به فر آيند ساز گارى با تغييرات به
فعاليتهاى بازتابى، روند جلسات را مديريت مى كنند و سيس در جلسه بعدى با مراجع به بررسى نتايج

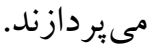

\section{ييشينه تحقيقات رهيارى در خانواده}

اگرجه وازه رهيارى خانواده اخيراً در ادبيات رهيارى معرفى شده است، اما رهيارى خانواده در ادبيات تحقيقى به خوبى مستند شده است. به عنوان مثال، تحقيقاتى كه به اثربخشى رهيارى اشاره شده است شامل مقالاتى در مورد

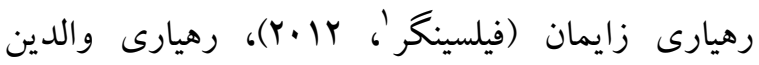

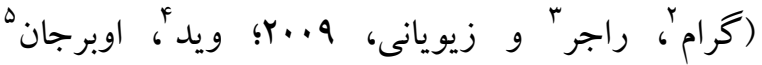

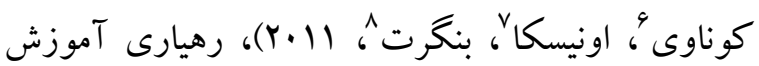

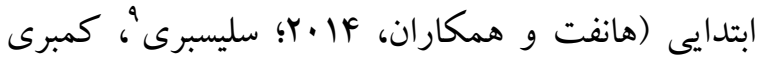

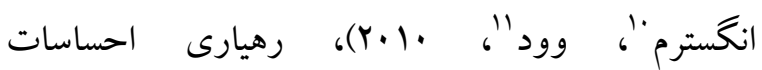

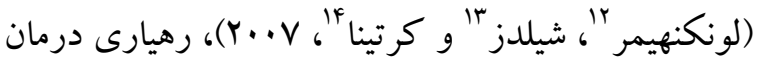

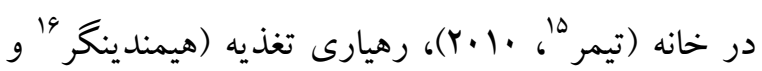

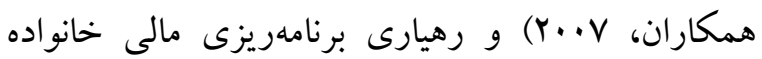

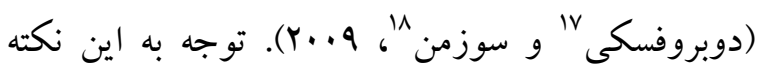

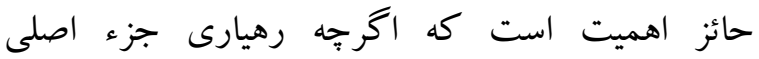
مداخلات نشان داده شده در اين مقاله ها محسوب مى

\footnotetext{
1- Filsinger

2- Grahm

3. Rodger

4- Wade

5 - Oberjohn

6. Conaway

7. Osinska

8- Bangert

9- Salisbury

${ }^{10}$ - Cambray-Engstrom

11- Woods

${ }^{12}$ - Lunkenheimer

13- Shields

14- Cortina

15- Timmer

16- Heimendinger

17 - Dubofsky

18- Sussman
} 
ساز گارى مى تواند بهعنوان هدف رهيارى يس از طلاق در نظر گرفت كه فرد طلاق گرفته يك گذار موفق را تجربه كند. در اين حالت فرد به جاى اين كه در گير افكار مرتبط با طلاق باشد به تعديل زندگى اش بس از طلاق

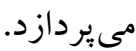
مطالعات بىشمارى حاكى از آن است كه تهديدهاى جنبه هاى معنادار هويت مى تواند با اختلال در هويت و مشكلات ساز گارى ارتباط داشته باشد (تويز، (1991). اين ساز كارى به معنى يافتن راههاى جديدى است كه فرد ارد بتواند اطلاعات جديدى كه با جنبهاى برجسته هويت او درگير است را با طرحوارههاى موجود شخصيتش تلفيق نمايد. تهديدهايى كه هويت اصلى فرد، هويت تعميميافته درونى، يا هويتى كه در مراتب بالاى ردهه مراتب هويت قرار دارد، با سطوح بالاترى از ناساز گارى مرتبط است. در نظريه هويت فرض بر اين است كه از دست دادن جنبه برجسته شخصيت است كه موجب مى شود از دست

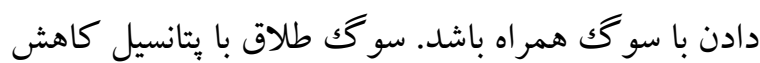
بهزيستى همر اه است كه علت اصلى آن مشكلات اصلى

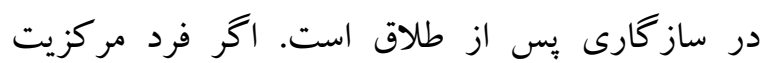
هويتش را با هويت از دست رفته تلفيق كرده باشد

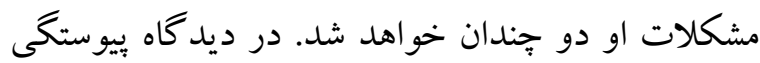
هويت افرادى كه هويت خودشان را بهطور بيوسته در نظر مى كيرند بهزيستى روانشناختى بالاترى دارند. كسانى كه استمرار هويت دارند مفهوم ذهنى كه از خود دارند را در بستر زمان تفكيك نمى كنند و خودشان در كذشته، حال و آينده بهصورت يكك كل در نظر مى گيرند. طلاق بديده ايست كه زمانى كه فردى با آن درگير مىشود، آرزوهايش، هويت خانواد گیىاش و برنامههايى كه براى آينده خود در نظر داشته همه به يككباره با اين بديده از هورئ
وجود آمده يس از يديده طلاق اشاره مى كنند كه طى آن فرد يس از بروز طلاق به بهزيستى هيجانى و روانشناختى دست مى يابد. ساز گارى بس از طلاق تحت عنوان فرايند تطابق با تغييرات زندگى حاصل شده از طلاق و و دستاوردهاى روان شناختى و هيجانى آن تعريف شده است اين تعريف شامل هر دو شاخص ساز گارى و عدم

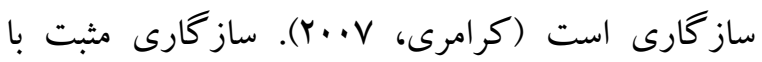
طلاق به عواملى جون رهايى از علائم و نشانهاى

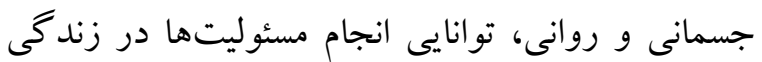
روزانه در خانه و محل كار بهرهورى از اوقات فراغت و رشد و استقلال فردى تعريف مىشود به طورى كه زندكى فرد با وضعيت تأهل و يا همسر سابقش گره

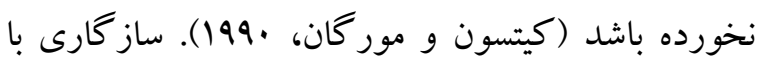
طلاق تلاشى است كه يكك فرد انجام مىدهد تا با تغييراتى كه در دوران كذار يس از طلاق با آن مواجه

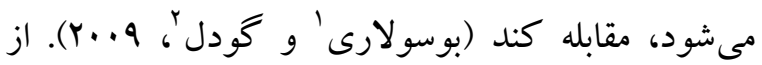
منظر سيستمهاى بييجيده انطباقى'؛ انسانها ذاتاً سطح بالايى از ظرفيت انطباقى دارند، به صورتى كه به آن ها امكان مى دهد كه به جاى اين كه فقط به صورت

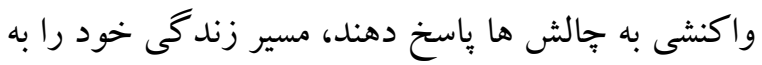
صورتى كه مى خواهند شكل دهند. نتيجه اينكه اين روند به آن ها احساس شخصيت و هويت شخصى مى دهد

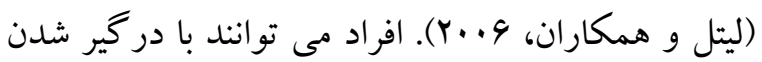
در تمرين هاى رشد شخصى مانند توسعه انعطاف يذيرى خلاق در تصميم گيرى و حل مسئله، ظرفيت ساز گارى

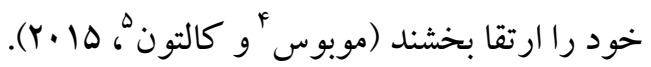

\footnotetext{
1. Bussolari

${ }^{2}$ - Goodell

${ }^{3}$ - Adaptive systems perspective

4- Mobus

- Kalton
} 
در مورد طلاق تعيين شده است، راحت تر كند، در نتيجه استرس در طول فر آيند طلاق راهم كاهش مىدهد. تابه امروز در مراجعينى كه بِ از طلاق در فرايند سوگك بس از طلاق قرار مى گيرند هيج تحقيقى صورت نكرفته است. رهيارى با بازسازى هويت مطابقت دارد زيرا اين رويكردى تجربى است كه به افراد كمكك مى كند تا روايت هاى شخصى خود را براى دستيابى به ديد كاه هاى تازه تجديد نظر كنند، به دنبال فرصت هاى جديد و ورئ

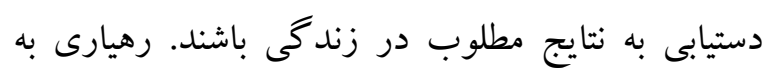

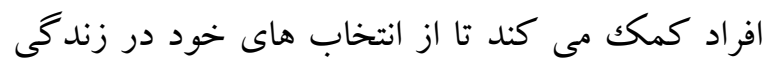
آكاه شوند و به نوبه خود فرصتى را براى آنها فراهم مى كند كه داستانهاى متعددى را كه هويت آنها را تشكيل مى دهد بازبينى كنند و داستان شخصى خود را

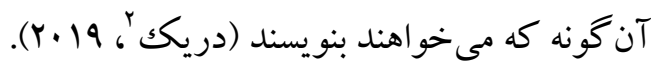
تغيير هويت در رهيارى مى تواند با استفاده از سؤال بازتابى تسهيل شود كه فرد را در تفكر درباره سيستم باورهاى خود توانمند مى كند و ايجاد ارتباطات جديد را تسهيل مى كند. اين فرايند بر اين مبنا است كه فرد بتواند تعاملات خود را از طريق دروننگرى هنگام وقوع مورد بررسى قرار دهد. سؤالهاى بازتابى افراد را ترغيب

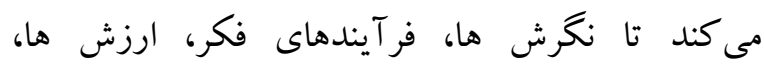
فرضيات، يِي داورى هاى خود رازير سؤال ببرند، نقش

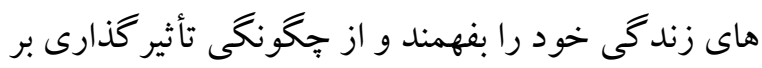

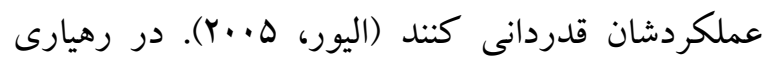
سؤالات انعكاسى ابزارى اساسى براى تسهيل خود آكاهى

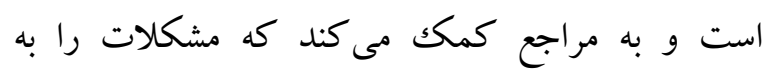

2- Drake
بين مىروند به همين جهت يس از طلاق جون فرد

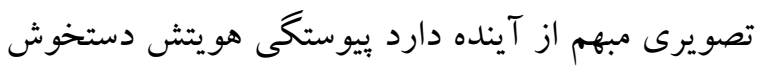
از هم ياشيدگى مىشود و اكر در اين زمان شروع به ساختن آينده نكند ساز گارى با شرايط برايش سخت

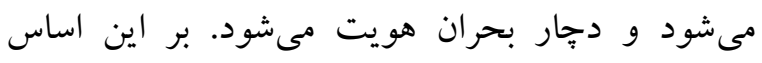
مداخلات متمركز به حال و آينده كه به وى كمك مى كند تا از مراحل سوگك بحذرد و تصويرى واضح از

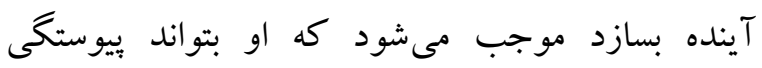
هويتش را حفظ نمايد و به بهزيستى روانشناختى بالاترى دست يابد. در اين زمان رهيارى بس از طلاق به اين مهم مىيردازد كه افراد خود را از نو تعريف كنند، هويتى دلخواه با سلامت روان و بهزيستى بالاترى بسازند.

\section{رهيارى پس از طلاق}

اكر جهه مشاوره طلاق براى زوجها در سيستم دادگًاه خانواده است، يكك رويكرد جديد به موفقيت خانواده استفاده از رهياران طلاق است. يورتنوى' (4. . ب) توضيح داد كه جطور و كلا شروع به استفاده از رهياران طلاق به آنه عنوان راهى براى كمكك به مو كلان و يرونده ى آن ها

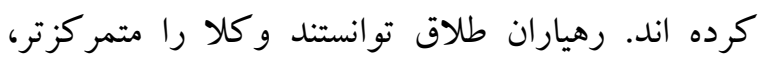
هدف گراتر و با آرامش بيشتر در طول استرس روانى

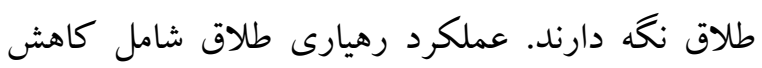
احساسات، راحت تر كردن روند قانونى، ايجاد راه حل، مديريت تضادها بوده است. رهياران طلاق بر يكك فر آيند مشار كتى و حل مسئله در طول جلسات تمركز مى كنند (برتنوى، 9. (Y). به طور كلى رهيارى مى تواند فر آيند طلاق را از طريق متمركز كردن مراجع بر هدفهايى كه 
مشكلات يا جِگونكى يبشرفت بيشتر خود ارائه دهد. تخيل فعال با استفاده از اشكال خلاق مختلف، مانند تصويرسازى ذهنى، تخيل در حالت آرامش، تجسم، كفتگگ با صداى درونى و يا با ديخران، بيان احساسات از طريق نمادهاست و اين يكك عملكرد ذهنى ذاتى است (يونگَ، 19YA). تصاويرى كه در جشم ذهن فرد ظاهر مىشود، معمولاً حاوى نمادها و معناى نمادين است. هنگامى كه افراد براى يافتن راه حل يا اجراى تغيير در سطح شناختى، عاطفى يا رفتارى تلاش مى كنند، دانش

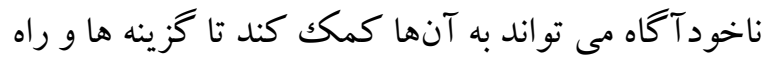
حل هاى جديد را بيدا كنند (بومن هو هندراكى'، 19 •.r). تمرينات ذهنى به طور فزاينده اى در رهيارى استفاده مىشوند و اين شامل استفاده از تصويرسازى ذهنى از

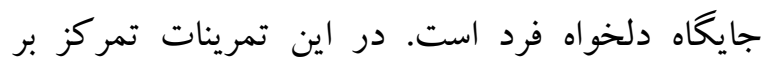
هويت و كشف هويتهاى احتمالى در بازسازى هويت بسيار تأثير گذارند. تمرينات ذهنى عامل مهمى در فرايند رهيارى دارند است، به طورى كه كه مراجع تجربه مشاهده و در گير شدن در صحنه رادارد. در اين تمرين ها هارئ فرد احساس كنترل بر نتيجه بازى را تجربه مى كند

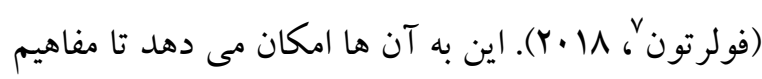
جديدى از خود و جهان را توسعه دهند و مهارت هاى

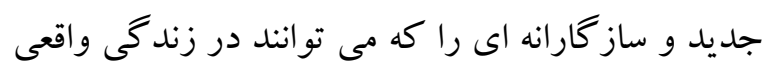

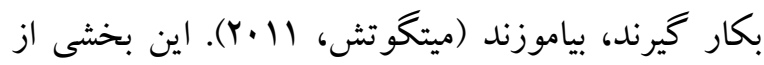
ياد گيرى مبتنى بر تصويرسازى ذهنى است كه در آن فرد يكك مدل ذهنى را ايجاد مى كند كه با سيستم ارزشهاى برى اصلى زندكى اش مطابقت دارد كه به نوبه خود كه در آن
صورتى جديد مفهوم بردازى كنند و نهايتاً راه حل جديد

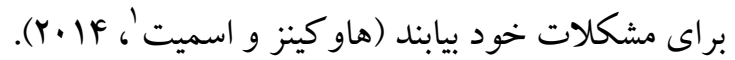

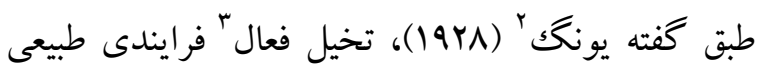
است كه نه تنها يكك تكنيك است براى بهبودى فردى مفيد است. است. اين تكنيك را مى توان از طريق اعمال خلاقانه مانند رقص، نقاشى، كاردستى يا نوشتن انجام داد، همجنين از اين روش در حالت آرامش ذهن و تجزيه و تحليل رؤياها نيز مى تواند مورد استفاده قرار گيرد. اشكال مختلف تخيل فعال وجود دارد. از طريق تخيل فعال و روشهاى متفاوتى كه از آن استفاده مىشود، بلى بر روى شكاف بين خود آكاه و ناخود آكاه زده مىشود و فاصله بين فانتزى و ديدگاه آكاهانه قابل گذر مىشود. تخيل فعال با تصاوير كار مى كند كه از طريق ناخودآكاه و بدون انتخاب فعالانه آنها به ذهن مى رسد. قسمت فعال آن از زمانى شروع مى شود كه فرد با خيال بردازى، خود درگير شود. بهطور مثال زمانى كه فرد آن صحنه را مشاهده مى كند، كفتگگ مى كند و يا حتى به صحنه وارد مىشود دقيقاً زمانى است كه فرد در آن فرد بهصورت

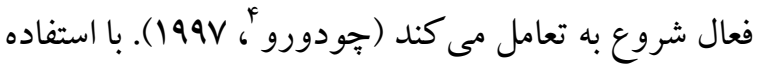
از تخيل فعال، تمر كز فرد به سمت دنياى درونى سوق مى يابد تا ناخود آكاه خود را به صورت نمادين بيان كند. از

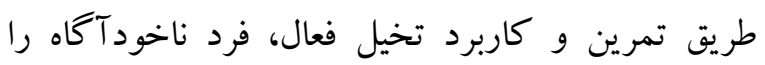
كشف مى كند و از اين طريق بينش عميقترى نسبت به دنياى درونى بيدا مى كند و اطلاعات جديدى در مورد خود كسب مى كند. تخيل فعال مىتو اند ايدهاى جديدى

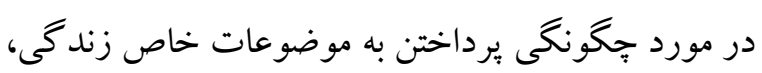


سو گى است كه توسط اليزابت كوبلر راس در مرگك

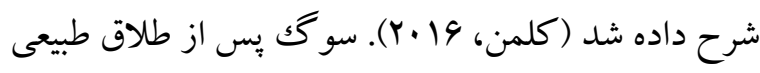
است، اما اكر شدت سو گك بيش از حد باشد يا دوره آن طولانى شود، روند مشاوره لازم مىشود. در عين حال وقتى فرد يس از طلاق در هر يك از مراحل باشد احتمالاً

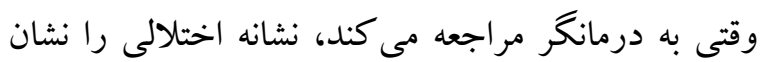
مىدهد كه ممكن است در رويكردى آسيب شناسانه اين فرايند طبيعى را وارد مراحل روان درمانى و يا حتى

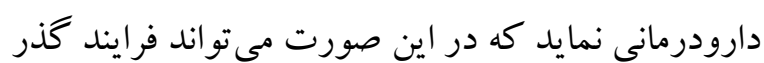
او بييجيدهتر شود. از آنجايى كه اين فرايند يكك فرايند

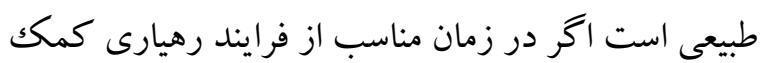
بحيرد با كمترين آسيب مى تواند با هيجانات مرحله مورد نظر كنار بيايد و از مرحله مورد نظر بحذرد. بر اساس مدلهاى نظرى و عملى كه در بالا بيان شد، براى هدايت مراجع به سمت خود جديدش نياز است كه

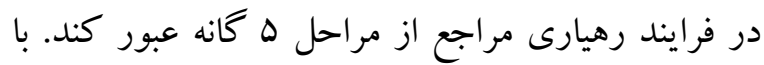
توجه به اين كه در هر مرحله مراجع بايد با احساسات

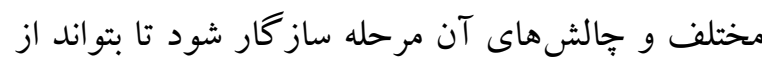
مرحله مورد نظر عبور نمايد، در هر يكك از مراحل از يكك سرى تمرينات استفاده مىشود تا بتواند آن مرحله و

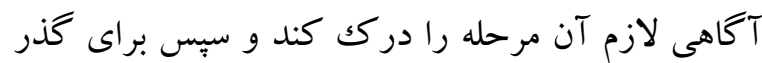
از آن مرحله اقدامات لازم را انجام دهد. به همين منظور اين مراحل را مد نظر قرار مىدهيم و تمرينات لازم براى آنها را ذكر خواهيم كرد. اكر مراجع در مرحله انكار باشد مرحله اول از يذيرش

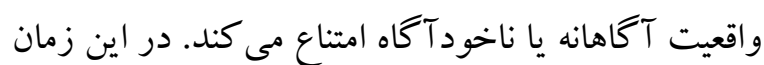
ممكن است حتى اظهار كند هيج اتفاقى در زندگى اش

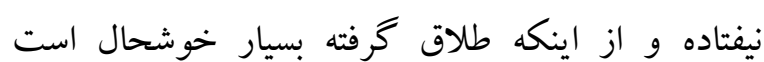

دنياى واقعى را مدل سازى مى كند (واسرمن' و بانكز '، .$(Y \cdot) \mathrm{V}$ كوبلر راس "روند سوگك در تغييرات زندگى فردى

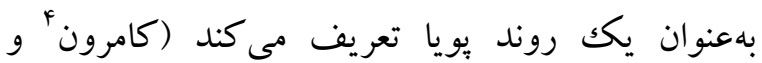

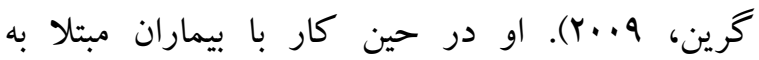
بيمارىهاى لاعلاج دركك كرد كه تغيير در دنياى خارجى باعث مى شود فرد ه مرحله مختلف انكار، عصبانيت، جانه زنى، افسردگى و پِذيرش را بهصورت درونى طى كند. در مرحله انكار، فرد تغييرى كه به زندكى او تحميلشده را نمى بذيرد، در مرحله خشم تمام دنيا را بر از محدوديت مىبيند و جهون فكر مى كند توانايى تغيير شرايط را ندارد و نمىتواند به جيزى دست يابد از همه كس و همه جيز عصبانى است و به شدت تحريك پذير مىشود. در مرحله سوم هنگامى كه فرد به

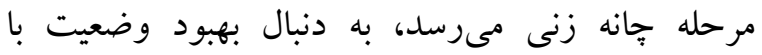
باز گشت و اصلاح شرايط قبل است. يس از آن در مرحله جهارم فرد ناميد از بذيرش تغيير مىشود و وارد مرحله

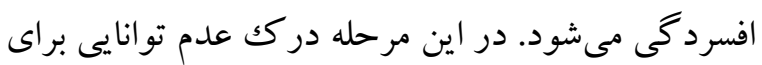
فرار از شرايط يِش آمده دست از همه جيز مىشويد و نشانهاى افسردگى را نشان مىدهد. بِ إس از مرحله افسردگى، كويلر راس آخرين مرحله كه يذيرش است را

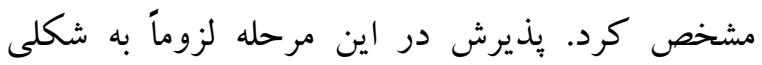
دليذير تجربه نمىشود اما فرد مىيذيرد كه هيج راه بر گشتى وجود ندارد و جارهاى ندارد مخر اين كه در اين

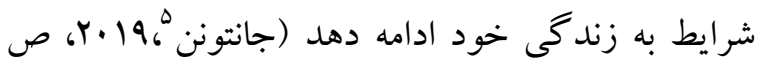
19). سوك از دست دادن يكك ازدواج، مانند روند

\footnotetext{
1. Wasserman

${ }^{2}$ - Banks

${ }^{3}$ - Kubler-Ross

${ }^{4}$ - Cameron

5 - Jantunen
} 
سلز "، وايكز "، (1) (Y). در اين زمان اين خشم يا معطوف به خود و يا معطوف به ديخران باشد كه اين هيجانات ممكن است سيستم تصميم گيرى او را مختل نمايد. در اين زمان ذهن آكاهى براى تنظيم شناخت و هيجانات فرد بسيار مهم است و از واكنش هاى خودكار در برابر

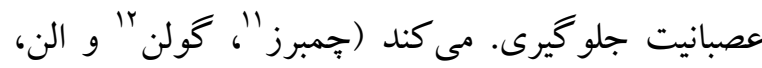

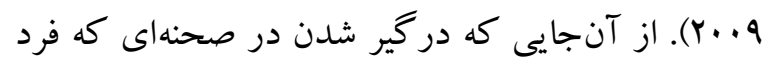
در حال واكنش هيجانى است ممكن است او را مستعد انجام آن عمل نمايد مراجع به تمرينى هدايت مىشود كه تماشاگر صحنهاى است كه در آن با عصبانيت رفتارى هيجانى انجام داده است. در تماشاى اين فيلم توجه مراجع را به حالات بدنىاش و زبان بدنش در زمان عصبانيت معطوف مىشود. بعلاوه جون مراجع نياز دارد كه عواقب ناشى از رفتارش را بازبينى كند، در ادامه وى رادر حال

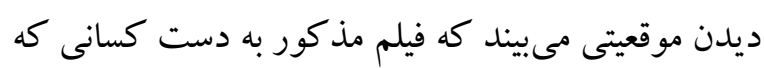
براى او مهم است رسيده باشد. در اين شرايط به مراجع كفته مى شود كه اخر قدرتى داشته باشد كه اين فيلم رابا لمائ فيلمى كه باعث مىشود وجهه و اعتبارش بيشتر شود عوض كند جهه صحنهاى را جايگزين آن خواهد كرد. در فرايند تغيير صحنه از وى درباره ارزشهايى كه در فيلم به بينده القا مى كند سؤال مىشود و از كلمات ارزشى و و وله انخيزشى خود مراجع استفاده مىشود كه بتواند موقعيتى

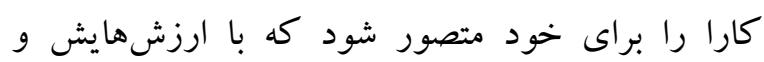
افرادى كه براى او و اعتبارش مهم هستند درگير كند. در اين قسمت تمرين مراجع هدايت مىشود كه در صحنه وارد شود تا بتواند احساس رضايت درونى آن صحنه را

${ }^{9}$ - Sells

10. Wykes

${ }^{11}$ - Chambers

12 - Gullone

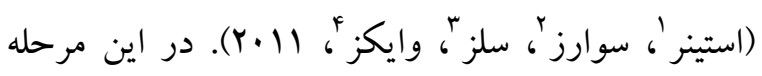
مراجع نياز دارد كه با واقعيت موجود روبرو شود. از اين رو بهترين تمرين براى او اين است كه در يك تمرين ذهنى او را در آرامگاهى قرار دهيد كه قبرهاى آن تمام آن جيزهايى است كه فرد به خاطر جدايى از دست داده است. ارتباطات، هويت خانوادكى، آرزوهايش براى يك هـ

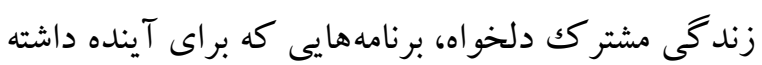
همه اين ها نوشته هايى روى قبرهاى اين آرامكاه دارند كه با برسشهايى از مراجع مىشود ديخر فضاهايى كه با طلاق از دست داده را با آنها مواجه مىشود. بعد بعد از تمرين رهيار از او مىخواهد كه با تجربهاى كه در تمرين داشته به بازتعريف شرايطش بيردازد. از سوى ديخر

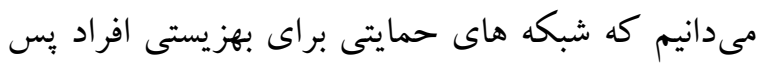
از طلاق بسيار مهم است. به همين منظور به وى كمكك مىشود كه فضاهايى كه مى تواند حمايت دريافت كند را شناسايى كند جرا كه تحقيقات نشان داده است كه روابط شبكهاى به طورى كه فرد بخشى از يك كروه باشد، بيش

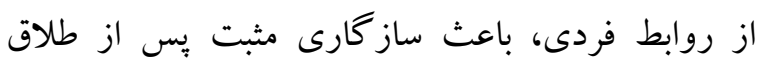

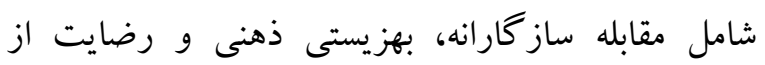

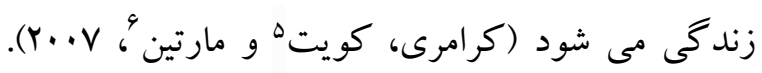
بِ از آن برنامه عملياتى استفاده از اين شبكه رهاى حمايتى در دستور كار جلسه قرار داده مىشود. مراجعى كه در مرحله خشم قرار دارد هم از خودش و هم

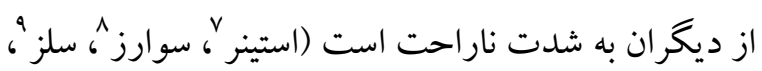


در مورد موقعيت كنونىاش ببرسد. رهيار نيز مىتواند جند سؤال در مورد نحوه برخورد آن جنبه از شخصيتش با اشتباهات بيرسد. يس از اينكه مراجع از تمرين خارج شد. در برنامهريزى براى تأليف خانكى از مراجع سؤال

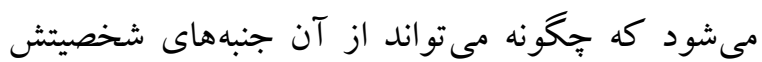

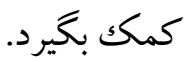
وقتى مراجع در مرحله افسردگى است. فكر مى كند هيج كارى از دستش بر نمى آيد و احساس ناميدى و ناتوانى مى كند. در اين زمان جرخه زندگى استفاده مى شود. در اين تمرين از مراجع خواسته مىشود تا ميزان رضايت خود را از رضايتمندى بايين (1) تا رضايتمندى بالا (.) در بين هشت حوزه زندكى خود شامل شغل، دارايى، سلامتى، دوستان و خانواده، رشد شخصى، معنويت، سر گرمى و تفريح و ارتباطات اجتماعى بر اساس ارزيابى خود از حوزه هايى كه ميزان رضايت آنها بايين تر است، اين تمرين يكك تمرين مداد كاغذى است كه به مراجع امكان مىدهد كه درك كند كه در ميان حوزههاى مختلف زندكىاش كداميك بيش از همه نياز به رسيدگى دارد. بعد از اين تمرين وقتى حوزه مورد نظر شناخته شد به مراجع كمكك مىشود كه هدفى هر جند

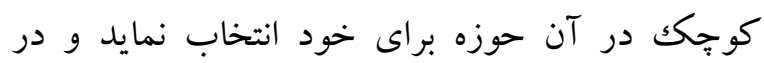
تكليف خانكى برايش اقدامات لازم را انجام دهد. در مرحله بذيرش مراجع كاملاً آمادگى دارد كه براى آيندهاش برنامهريزى نمايد. به همين منظور در اين مرحله لزوم ساختن جشم انداز براى آينده ملموس مى بـوده. رهياران از سلسله مراتب سطوح منطقىه براى ساختن جشم انداز استفاده مى كنند كه بر اساس مدل رابرت
نيز بهصورت درونى تجربه نمايد. توجه مراجع در اين زمان نيز به حالات بدنى اش معطوف مىشود و تحسين در جهره افراد مهم اش نيز مورد سؤال قرار مى گيرد. در اين حالت نيز بس از تمرين مراجع به تكليفى هدايت مىشود كه بتواند زمينهساز ايجاد فرصتى براى تجربه واقعى تصوير بازسازى شده باشد.

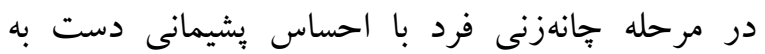

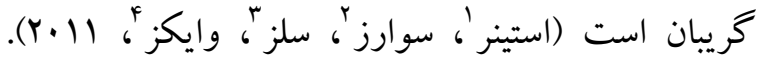
معمولاً در اين زمان مراجع از بسيارى از كارهايى كه انجام داده احساس ندامت مى كند و افسوس كارهايى كه انجام نداده را مىخورد. او در اين مرحله قادر به بخشيدن خود نيست به همين منظور تمرينى نياز داريم كه مراجع بتو اند در روند بخشش خودش قرار بـيرد. از آنجايى كه در اين زمان مراجع دائماً خود را سرزنش مى كند مواجهه با موفقيتهايش وى را در شرايطى قرار مىدهد كه ارزشمندىهاى خود را نيز مشاهده كند. در اين مرحله ابتدا از مراجع در مورد دستاوردهايش سؤال مىشود و از وى خواسته مىشود كه سه موقعيت را كه در آن خودش را تحسين كرده به خاطر آورد و براى هر كدام از شرايط

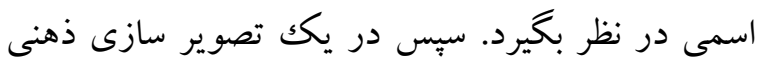
مراجع ابتدا خودش را در يكك تصوير در يكك اتاق امن فرض نمايد. سبس از وى خواسته مىشود به حالات بلدنى اش توجه نمايد. بعد از آن از وى خواسته مىشود كه خودش را در سه موقعيت ذكر شده با اسمهاى مورد نظر دعوت به اتاق كند. يس از حضور ب تصوير از خودش

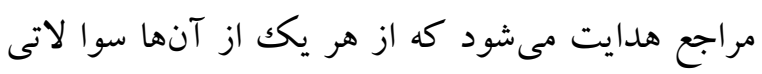




\section{نتيجه كيرى}

هدف اين مقاله تبيين مبانى نظرى رهيارى بس از طلاق و توصيف تمرينات كاربردى بهعنوان بخشى از تلاش براى برنامهنويسى بزرك تر براى حر كت به سمت طرح ارزيابى دقيق تر است. بر اساس آنجه كفته شد به نظر مىرسد رهيارى يس از طلاق رويكردى منحصر به فرد در مورد

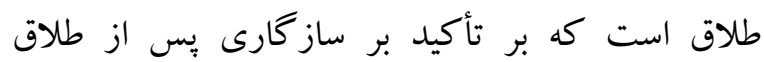

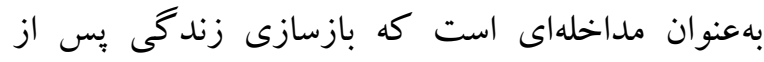
طلاق را تسهيل مىنمايد. رهيارى پِ از طلاق به طور صريح تحت تأثير ادبيات نظرى و تجربى ناشى از حوزه

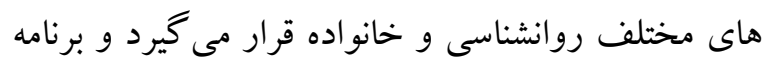
اي بويا مبتنى بر نقاط قوت، ايجاد مى كند. رهيارى بس از

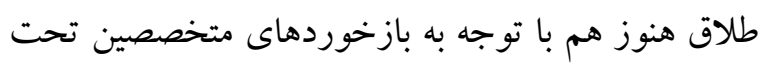
تأثير تئورى هاى علوم خانواده، شواهد تحقيق و يافته هاى ارزيابى، در حال رشد و تغيير است. قلب نظريه رهيارى يس از طلاق ريشه در اين اعتقاد دارد كه با ساختن هويت مورد دلخواه براى فرد و كمكك به اقدامات لازم جهت كم كردن فاصله بين تصوير ذهنى فرد از خودش بس از طلاق و خود ايدهآلش او را در روند رشدى قرار مىدهد كه بتواند علاوه بر ساز گارى با طلاق به سمت بهزيستى روانشناختى حركت نمايد. متناسب با ماهيت رهيارى ״ّ از طلاق، مداخله در هر زمانى يّ از طلاق، مى

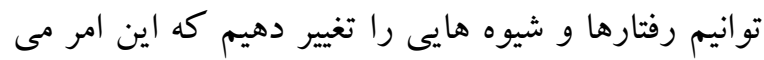

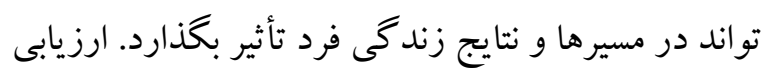
مداخله رهيارى بس از طلاق، توسط تحقيقات كاربردى

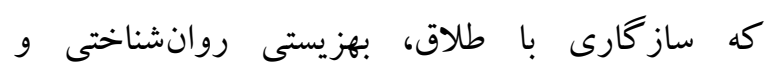
تاب آورى را هدف قرار دهند خودنمايى مى كند. نتايج

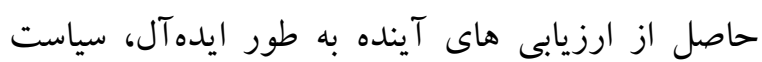

ديلتس است. ديلتز 'مدل را به عنوان يكك سلسله مراتب به سبك هرمى ارائه مى دهد. مطابق مدل، شش سطح وجود دارد (معنويت (ارتباط با ديخران و دنيا)؛ هويت؛ باورها و ارزش ها؛ قابليتها؛ رفتار؛ و محيط). هر سطح فعاليتهاى سطح زيرين آن را سازماندهى و هدايت مى كند؛ بنابراين لزوماً تغيير جيزى در سطح بالاتر تغييراتى را در سطح پايينتر ايجاد خواهد كرد. در مقابل، تغيير در سطح پايين تر لزوماً تغييرى در سطوح بالاتر ايجاد نمى كند. البته ناكفته بيداست كه سطح بالاتر بدون سطح فورى زير نمى تواند توسعه يابد (فاضل، سا •Y). در اين جلسه مراجع در يكك تمرين ذهنى با خود ايده آلث ملاقات مى كند و با تمركز بر ب سطح بالايى مدل ديلتز تغييراتى كه لازم

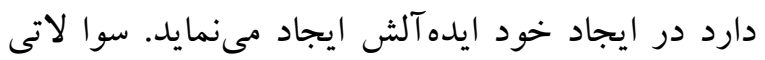
كه از خود ايدهآلش برسيده مىشود به وى اين امكان را

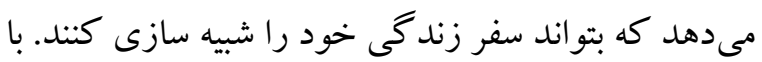
سؤال از اينكه و همجنين دليل اصلى زندگى اش راو تأثير آن بر هويت خود بيابد، ارزشهايش را تعيين كند و

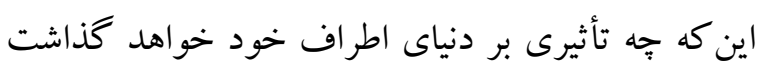
را بررسى نمايد. به نوبه خود، او مى تواند هدف را بر اساس خود ايده آل خود تغيير دهد. در ادامه فرايند رهيارى در افراد مطلقه و ديخر افراد تفاوت جندانى ندارد و با استفاده از تكنيككها و ابزار شناخته شده در رهيارى بر اساس آنجه در روانشناسى رهيارى ذكر شده است مراجع به سمت برنامهريزى براى رسيدن به هويت مورد علاقهاش اقدام خواهد كرد. 
Allen K, Huffl N L. (2014). Family Coaching: An Emerging Family Science Field. Family Relations. 63(5), 569-582.

Allen K. (2016). Theory, research, and practical guidelines for family life coaching. Springer.

Arber S, Bote M, Meadows R. (2009). Gender and socio-economic patterning of self-reported sleep problems in Britain. Social science medicine, 68(2), 281-289.

Baumann M, Handrock A. (2019). Shame and Forgiveness in Therapy and Coaching. In The Bright Side of Shame. Springer, Cham, 471487.

Bono J E, Purvanova R K, Towler A J, Peterson, D B. (2009). A survey of executive coaching practices. Personnel Psychology, 62(2), 361404.

Brennan D, Prior D M. (2005). The future of coaching as a profession: The next five years 20052010. Lexington, KY: International Coach Federation.

Campbell M A, Gardner S. (2005). A pilot study to assess the effects of life coaching with Year 12 students. Evidence-Based Coaching Volume 1: Theory, Research and Practice from the Behavioural Sciences, 159.

Carter A D, Bloom G A. (2009). Coaching Knowledge and Success: Going Beyond Athletic Experiences. Joumal of Sport Behavior, 32(4).

Chambers R, Gullone E, Allen N B. (2009). Mindful emotion regulation: An integrative review. Clinical psychology review, 29(6), 560-572.

Chodorow J. (1997). Jung on active imagination. Princeton. Princeton University Press.

Coleman M, Morgan M. (2016). Divorce and adults.

Corcoran P, Nagar A. (2010). Suicide and marital status in Northem Ireland. Social psychiatry and psychiatric epidemiology, 45(8), 795-800.

DeAngelis T. (2010). First-class coaching. APA Monitor, 41, 10-48.

Douglas C A, McCauley C D. (1999). Formal developmental relationships: A survey of
هايى رادر مورد دستورالعمل هاى آموزش يس از طلاق و همجِنين بهبود مداوم برنامه ها را ممكن مىنمايد.

در تعريف رهيارى خانواده به عنوان يك زمينه منحصر به فرد و جداكانه در علوم خانواده، كار بيشترى لازم است جرا كه يكك رشته يكك حرفه ای نياز به شرايطى دارد كه زمينه مدارك تحصيلى و كد اخلاقى خاصى را رعايت كند و داراى مداركك معتبر باشد كه شامل اعتباربخشى و ساعات ارائه شده و مقررات وضع شده توسط دولت باشد. رهيارى خانواده يكك زمينه ابتكارى است كه هنوز همه اين الزامات را بر آورده نمى كند، اما در بين رهياران خانواده حركتى وجود دارد تا اقدامات لازم را براى ايجاد رهيارى خانواده به عنوان يكك رشته انجام دهد. تحقيقات بيشترى در مورد استفاده مؤثر از رهيارى با خانواده هاى داراى عملكرد كمتر و ياد در حال فروياشى و يا از هم پِاشيده مورد نياز است (الن،

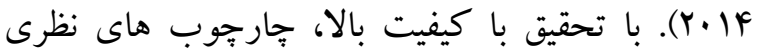
مفصل تر و توجه به رابطه بين رهيارى بس از طلاق و حرفه هاى مرتبط با آن، رهيارى مى تواند به عنوان يك استراتزى مهم براى كمكك به خانواده ها در ايجاد نقاط قوت و افزايش عملكرد سالم آنها رشد كند. ولى تا زمانى كه تحقيقات كاربردى در اين زمينه وجود نداشته باشد در مورد كارايى آن نمىتوانيم نظرى اساسى دهيم. بر اين اساس مداخلات مبتنى بر شواهد لازم داريم كه با

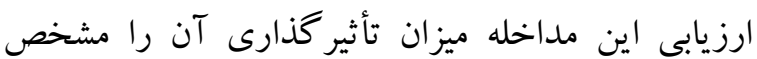

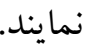

\section{References}


Adult Institution. Social and Behavioral Sciences, 97, 384-391.

Fthenakis W E. (2014). Divorce as a family transition interventions for divorced parents and children.Family and Conciliation Courts Review, 30, 34-49.

Fullerton T. (2018). Game Design Workshop: A Playcentric Approach to Creating Innovative Games. 4th Edn. Boca Raton, FL: CRC Press/Taylor Francis.

Gardner J, Oswald A J. (2006). Do divorcing couples become happier by breaking up?. Joumal of the Royal Statistical Society: Series A (Statistics in Society), 169(2), 319-336

Goode WJ. (1965). Women in divorce: Free Press.

Gorby CB. (1937). Everyone gets a share of the profits. Factory Management Maintenance, 95, 8283.

Grant A M, Curtayne L, Burton G. (2009). Executive coaching enhances goal attainment, resilience and workplace well-being: A randomised controlled study. The Journal of Positive Psychology, 4(5), 396-407.

Grant A M, Palmer S. (2002). Coaching Psychology Meeting held at: the Annual Conference of the Division of Counselling Psychology. British Psychological Society. Torquay, 18.

Grant A M, Passmore J, Cavanagh M J, Parker H M. (2010). 4 The State of Play in Coaching Today: A Comprehensive Review of the Field. International review of industrial and organizational psychology, 25(1), 125-167.

Grant AM. (2001). Towards a psychology of coaching. University of Sydney, Coaching Psychology Unit, School of Psychology, New South Wales, Australia.

Grant AM. (2003). The impact of life coaching on goal attainment, metacognition and mental health. Social Behavior and Personality: an intemational joumal, 31(3), 253-263.

Grant A M. (2006). An integrative goal-focused approach to executive coaching. In D R Stober A M Grant (Eds. ), Evidence based coaching handbook: Putting best practices to work for your clients, Hoboken, Wiley, 153-192. organizational practices. Human Resource Development Quarterly, 10(3), 203-220.

Drake D B. (2018). Narrative Coaching: The Definitive Guide to Bringing New Stories to Life. CNC Press.

Fazel P. (2013). Learning Theories within Coaching process. International Joumal of Social, Behavioral, Educational, Economic, Business and Industrial Engineering, 7(8), 2343_2349.

Fazel P. (2013). Teacher-coach-student Coaching Model: A Vehicle to Improve Efficiency of

Grant A M. (2015). Coaching the brain: Neuro-science or neuro-nonsense. The Coaching Psychologist, 11(1), 31.

Green L S, Oades L G, Grant A M. (2006). Cognitivebehavioural, solution-focused life coaching: Enhancing goal striving, well-being and hope. Joumal of Positive Psychology, 1(3), 142-149.

Green M. (2009). Making Sense of Change Management: A Complete Guide to the Models, Tools Techniques of Organizational Change. Kogan Page.

Green S, Grant A M, Rynsaardt J. (2007). Evidencebased life coaching for senior high school students: Building hardiness and hope. International Coaching Psychology Review, 2(1), 24-32.

Green S. (2004). The efficacy of group-based life coaching: a controlled trial. Doctor of psychology thesis. Department of Psychology, University of Wollongong.

Griffith CR. (1928). Psychology and athletics: a general survey for athletes and coaches. Coleman Roberts.

Hawkins P, Smith N. (2014). "Transformational coaching," in The Complete Handbook of Coaching, eds Cox E, Bachkirova T, Clutterbuck D, editors. (London: Sage;), 231244.

Hayward J, Miller E, Jin R, Sampson N A, Alonso J, Andrade L H, ... Fukao A. (2011). A multinational study of mental disorders, marriage, and divorce. Acta Psychiatrica Scandinavica, 124(6), 474-486. 
Hayward M, Zhang Z. (2006). Divorced middle-aged women more prone to heart disease than those who remain married.Marriage and Family, 68(3), 639-657.

Higgins J P T, Green S E. (2013). Cochrane handbook for systematic reveiws.

Hudson F M. (1999). The handbook of coaching: A comprehensive resource guide for managers, executives, consultants, and human resource professionals, San Francisco: Jossey-Bass.

Ives Y. (2008). What is' coaching'? An exploration of conflicting paradigms. International Joumal of Evidence Based Coaching Mentoring, 6(2).

Jantunen R. (2019). Enabling Change through Coaching Approach.

Jung C G. (1928). The technique of differentiation between the ego and the figures of the unconscious. Collected works. Princeton, Princeton University Press, 341-373.

Kauffman C. (2006). Positive psychology: The science at the heart of coaching. Evidence based coaching handbook: Putting best practices to work for your clients, 219-253.

Kitson G C, Morgan L A. (1990). The multiple consequences of divorce: A decade review. Joumal of Marriage and Family, 52(4), 913.

Kramrei E, Coit C, Martin S, Fogo W, Mahoney A. (2007). Post-divorce adjustment and social relationships: A meta-analytic review. Journal of Divorce Remamiage, 46(3-4), 145-166.

Little D L, Snyder C R, Wehmeyer M. (2006). "The agentic self: on the nature and origins of personal agency across the lifespan," in The Handbook of Personality Development, eds Mroczek D, Little T D, editors. (Mahwah, Lawrence Erlbaum and Associates), 61-80.

Lorenz FO, Wickrama K A S, Conger R D, Elder JrG H. (2006). The short-term and decade-long effects of divorce on women's midlife health. Joumal of health and social behavior, 47(2), 111-125.

Madden W, Green S, Grant A M. (2011). A pilot study evaluating strengths-based coaching for primary school students: Enhancing engagement and hope. Intemational Coaching Psychology Review, 6(1), 71-83.

Middeldorp C M, Cath D C, Beem A L, Willemsen G, Boomsma D I. (2008). Life events, anxious depression and personality: a prospective and genetic study. Psychological medicine, 38(11), 1557-1565.

Miller G, Chen E, Zhou E. (2007). If it goes up, must it come down? Chronic stress and the hypothalamic-pituitary-adrenocortical axis in humans. Psychological Bulletin, 133(1), 2545.

Mitgutsch K. (2011). "Serious leaming in serious games," in Serious Games and Edutainment Applications, eds Minhua M, Oikonomou A, Jain L C, editors. (London: Springer-Verlag), 45-58.

Mobus GE, Kalton MC. (2015). Principles of Systems Science. New York, NY: Springer, 289-296.

Nicholson P J. (2007). How to undertake a systematic review in an occupational setting. Occupational and environmental medicine, 64(5), 353-358.

Oliver C. (2005). Reflexive Inquiry: A Framework for Consultative Practice. London: Kamac.

Palmer S, Whybrow A. (2018). Handbook of coaching psychology: A guide for practitioners. Routledge.

Pinquart M, Sorensen S. (2000). Influences of socioeconomic status, social network, and competence on subjective well-being in later life: A meta-analysis. Psychology and Aging, 15(2), 187-224.

Robinson T A. (2016). linking Insight To Behaviour Change In A Life Coaching Intervention For Women. Electronic Thesis and Dissertation Repository, 3988.

Rush D D, Shelden M L, Hanft B.E. (2003). Coaching families and colleagues: A process for collaboration in natural settings. Infants Young Children, 16(1), 33-47.

Sbarra D A, Law R W, Portley R M. (2011). Divorce and death: A meta-analysis and research agenda for clinical, social, and health psychology. Perspectives on Psychological Science, 6(5), 454-474. 
Sbarra D, Law R, Portley R. (2011). Divorce and death: A meta-analysis and research agenda for clinical, social, and health psychology. Perspectives on Psychological Science, 6(5), 454-474.

Sin NL, Lyubomirsky S. (2009). Enhancing well-being and alleviating depressive symptoms with positive psychology interventions: A practice-friendly meta-analysis. Journal of clinical psychology, 65(5), 467-487.

Spence G B, Grant A M. (2005). Individual and group life-coaching: Initial findings from a randomised, controlled trial. In M. Cavanagh, A M Grant T. Kemp (Eds. ), Evidence-based Coaching Vol. 1: Theory, research and practice from the behavioural sciences Bowen Hills, Qld: Australian Academic Press, 143 158.

Steiner L M, SuarezE C, Sells J N, Wykes S D. (2011). Effect of age, initiator status, and infidelity on women's divorce adjustment. Journal of Divorce Remarriage, 52(1), 33-47.

Stober D R, Grant A M. (2006). Evidence based coaching: Putting best practices to work for your clients. John Wiley \& Sons.

Theeboom T, Beersma B, Van Vianen A E. (2013). Does coaching work? A meta-analysis on the effects of coaching on individual level outcomes in an organizational context. The Journal of Positive Psychology, 1-18.

Waite L J, Luo Y, Lewin A C. (2009). Marital happiness and marital stability: Consequences for psychological well-being. Social Science Research, 38(1), 201-212.

Wasserman J A, Banks J. (2017). Details and dynamics: Mental models of complex systems in game-based leaming. Simulation Gaming, 48(5), 603-624.

Whitmore J. (1992). Growing human potential and purpose: The principles and practice of coaching and leadership.

Whitworth L, Sandhal P, Kimsey-House H, KimseyHouse K. (2009). Co-active coaching: New skills for coaching people toward success in work and life. Davies-Black.
Wilkins B M. (2000). A grounded theory study of personal coaching. Doctoral dissertation, ProQuest Information Learning.

Wiseman R S. (1975). Crisis theory and the process of divorce. Social Casework, 56(4), 205-212. 